\title{
Controlling Corruption in Development Aid: New Evidence from Contract-Level Data
}

\author{
Elizabeth Dávid-Barrett ${ }^{1}$ (D) Mihály Fazekas ${ }^{2} \cdot$ Olli Hellmann $^{3} \cdot$ Lili Márk $^{2}$ • \\ Ciara McCorley ${ }^{1}$
}

Published online: 28 October 2020

(C) The Author(s) 2020

\begin{abstract}
Following scandals about corruption in foreign aid, and in a political climate that increasingly questions the legitimacy of development assistance, donors are under pressure to better control how their funds are spent. However, there is little evidence on precisely how to control corruption in development aid. This article assesses under which conditions donor regulations are successful in controlling corruption in aid spent by national governments through procurement tenders. The article analyses data on donor-funded procurement contracts in 100+ countries in 1998-2008 and uses 'single bid submitted in a competitive tender' as a corruption risk indicator. Applying a contract-level propensity score matching and regression analysis, it finds that an intervention which increases donor oversight and widens access to tenders is effective in reducing corruption risks: lowering single bidding on competitive markets by 3.64.3 percentage points. This effect is greater in countries with low-state capacity.
\end{abstract}

Keywords Development aid $\cdot$ Public procurement $\cdot$ Corruption $\cdot$ State capacity $\cdot$ Party systems

\section{Introduction}

Donors are under pressure to demonstrate that their money is well spent. Intellectually, they must address concerns that development aid softens the budget constraints on recipient-country governments and interferes with electoral accountability, making it easier for them to spend irresponsibly or syphon off funds. Politically, scandals

Elizabeth Dávid-Barrett

e.david-barrett@sussex.ac.uk

1 University of Sussex, Brighton, UK

2 Central European University, Budapest, Hungary

3 University of Waikato, Hamilton, Aotearoa New Zealand 
showing how foreign aid has been embezzled weaken the support of donor countries' national electorates, particularly in a global political environment that is increasingly isolationist. Donors have responded by seeking to better control their spending, while balancing this against exhortations to build recipient government capacity.

Donors need a stronger evidence base about the mechanisms through which development aid is subverted by corruption. However, most research considers only whether the amount of aid increases corruption. This literature tends to rely on expert- and survey-based assessments of corruption at the country level as the dependent variable e.g. the World Bank's Worldwide Governance Indicators or Transparency International's Corruption Perceptions Index. These are based on subjective perceptions of corruption, insensitive to change, and focus heavily on the effect of corruption on business (Heywood and Rose 2014; Ko and Samajdar 2010; Razafindrakoto and Roubaud 2010; Lancaster and Montinola 2001). Moreover, they do not measure corruption in the spending of development aid specifically.

A second problem is that scholarship has failed to adequately incorporate the impact of donors' own anti-corruption mechanisms. The impact is likely to depend not only on the political economy context into which the aid is delivered but also on the way in which aid is delivered. However, this debate has typically lacked process-level data on how aid is spent.

A third problem is that, despite a growing literature on how the political economy context of a country affects corruption, very few studies incorporate these insights into analyses of the relationship between aid and corruption. Yet the recipient country context is likely to influence how easily aid spending becomes corrupted: there may be important interactive effects between donors' anti-corruption tools and contextual factors.

This paper contributes to the literature through addressing these weaknesses in the context of development aid spent through national public procurement systems; this represents the bulk of development funds, and is highly prone to corruption (Collier et al. 2015). First, we employ an innovative methodology that measures corruption risk in aid directly, based on an analysis of large datasets of donor-funded government contracts. Our methodology allows us to study procurement processes and outcomes at the level of contracts, identifying patterns of corruption risk across more than 100 countries over two decades. Second, we test the effectiveness of two widely pursued reforms: (i) increasing oversight and (ii) promoting competition among bidders. Operationally, we examine these through testing the November 2003 change to the World Bank's procurement rules for goods, works and services ${ }^{1}$; other major donors undertook similar reforms a few years later. Third, we employ a contract-level matching methodology to compare contracts awarded according to old and new rules within the same procuring organisations and countries. Fourth, we relate corruption risks in aid contracts to the rent-seeking regime type in recipient countries, operationalised along the dimensions of state capacity and party system institutionalization. Fifth, we investigate how donors' anti-corruption regulations interact with these local contextual factors. Overall, we seek to answer the question: does the effectiveness of donors' anti-corruption mechanisms depend on recipient-country characteristics?

\footnotetext{
${ }^{1}$ Note that this reform, despite being implemented in November 2003, is often referred to internally in the Bank as the '2004 reform'.
} 
We find that increasing oversight and widening market access decreases corruption risks: the share of aid-funded contracts that attracted only one bidder fell from about 22 to $18 \%$, a drop that is both statistically significant across all models estimated, and substantial in economic and policy terms. This effect is greater in countries with lowstate capacity, while the level of party system institutionalization does not amplify the intervention effect.

\section{Aid and Corruption: a Review of the Literature}

While a number of studies find that foreign aid fuels corruption (e.g. Asongu and Nwachukwu 2016; Busse and Gröning 2009; Bräutigam and Knack 2004), others find that aid reduces corruption in recipient countries (e.g. Mohamed et al. 2015; Okada and Samreth 2012; Tavares 2003). A third strand of academic work reports no significant effect of foreign aid on corruption (e.g. Ear 2007; Menard and Weill 2016). Other works delve into the incentive factors that affect whether aid spending is corrupted, pinpointing uncertainty (Kangoye 2013), size of inflows (Dalgaard and Olsson 2008), and ethnic and religious fragmentation (Svensson 2000) as relevant factors. Others argue that both donor and aid proliferation can dilute the governance agenda, creating space for discretionary behaviour with donor funds (Knack and Rahman 2007; Busse and Gröning 2009).

A number of studies have focused on the modality of aid distribution. For example, scholars debate whether general budget support or project aid is more effective in supporting development (Easterly and Pfutze 2008; Deaton 2013). Charron finds that multilateral aid is more effective in curbing corruption than bilateral aid (Charron 2011), while Öhler et al. (2012) reveals that the effectiveness of the Millennium Challenge Corporation's conditional aid strategy weakens over time.

However, as De Renzio (2006) points out, external factors-such as donor controls-interact with domestic factors. We know that the impact of anticorruption tools in general depends to a large extent on the environment in which they are implemented-for example, on the quality of the local accountability ecosystem (Brautigam 1992; Grimes 2013), the presence of rule of law in the recipient country (Mungiu-Pippidi and Dadašov 2017), the degree of media freedom (Brunetti and Weder 2003) and the competitiveness of elections for public office (Winters and Weitz-Shapiro 2013). It has also been argued that incentives for corrupt behaviour depend on elites' time horizons (e.g. Kelsall 2013; Khan 2010; Rock and Bonnett 2004; Wright 2008). Elites with long time horizons - for example, autocratic rulers who do not face significant challenges to their political authority or democratic politicians in a highly predictable electoral arena-face incentives to restrain corrupt activities and invest public resources towards economic growth, so that they can loot more in the long run. Elites with short-time horizons face incentives to steal as much as they can immediately after taking office.

In sum, the literature recognises the importance of interactions between disbursement method and recipient context, but few studies offer empirical evidence on how this works. Our article aims to contribute in this area. 


\section{Theoretical Framework}

\section{How Do Changes in Donor Regulations Affect Corruption?}

When it comes to corruption in the spending of aid, one set of institutions that shape elites' risk calculations in recipient countries are donors' own anti-corruption mechanisms. Since the poorest countries are also the most corrupt ones it is crucial for donors to control recipients' spending from aid funds via well-designed institutions (Easterly and Pfutze 2008.; Alesina and Weder 2002). Since the 2003 Rome Declaration, donors have sought to improve aid effectiveness through building capacity in recipient countries (OECD 2003) and tying aid to a good governance agenda that establishes strict conditions for how money is spent (Ellmers 2011; Charron 2011; Tavares 2003). However, this policy-related conditionality typically targets aid provided as budget support (White and Dijkstra 2003), and — although difficult to evaluate - seems to work better in some contexts than others (Cordella and Dell'Ariccia 2007; Dijkstra and de Kemp 2015; Caputo et al. 2011). In weak-governance and high-corruption contexts, donors prefer to use earmarked or project aid, which is subject to tighter controls (Radelet 2005) —even though this blurs donor and recipient ownership, thereby clouding accountability relationships (Kolstad and Fritz 2008). Increasingly, donors are reducing their exposure to institutional weaknesses by disbursing funds against outcomes (Perakis and Savedoff 2015) in "results-based aid".

Where aid is disbursed through national procurement systems, it is vulnerable to institutionalized grand corruption, whereby the rules and principles of good public procurement are subverted to benefit a closed network of cronies or allies while denying access to others (Mungiu 2006; North et al. 2009; Rothstein and Teorell 2008). In public procurement, there is an assumption that tenders will, by default, be open and fair, and that contracts will be allocated to the bidder with the most favourable offer, according to pre-determined criteria. Corruption occurs in public procurement when a contract is steered to a favoured bidder rather than being allocated according to principles of open and fair competition (World Bank 2009). This can be done in many ways, including by competition through unjustified sole sourcing or direct contracting, or by manipulating aspects of an ostensibly open process e.g. tailoring the specification of the tender or sharing inside information to benefit a favoured bidder (World Bank 2009).

In seeking to curb corruption in procurement, donors have two main regulatory strategies available to them: they can increase oversight over the spending of their funds or promote greater local competition by pressuring recipient governments into widening access to tenders. The first strategy is in line with economic approaches to corruption control (Rose-Ackerman and Palifka 2016; Klitgaard 1991). Regulatory reforms aimed at enhancing oversight over the spending of aid should reduce opportunities for corruption and strengthen the accountability of recipient governments. Several studies find that the threat of external audit reduces corruption (Olken 2007; Knack et al. 2017; Zamboni and Litschig 2018; Avis et al. 2016) and that intensive audits reduce prices for homogeneous goods (Di Tella and Schargrodsky 2003).

For the second strategy - widening access to tenders - donor organisations can demand that recipient countries use electronic advertisement to increase bidders' awareness of tender opportunities, building on empirical evidence that this improves competition (Kenny and Crisman 2016; Coviello and Mariniello 2014). Alternatively, donors can 
widen access to tenders through e-procurement methods which standardise various aspects of the bidding process and lower transaction costs, again in line with evidence that this increases competition (Fazekas and Blum 2020), reduces prices (Singer, Konstantinidis, Roubik, \& Beffermann 2009), achieves cost savings (Auriol 2006), and improves quality (Lewis-Faupel et al. 2016). To the extent that they increase competition, such measures should also indirectly increase scrutiny over the procurement process, by extending the group of stakeholders - unsuccessful bidders - with an interest in holding decision-makers to account. As long as this translates into a higher likelihood of detecting corruption, it will represent an additional constraint on corrupt elites. ${ }^{2}$

To sum up, regulatory reforms aimed at increasing oversight and widening access can decrease the opportunities and incentives for elites to corruptly manipulate the tendering process for prior-reviewed contracts to favour certain companies. Hence, we hypothesise:

H1: Increased donor oversight and wider access to tenders decrease corruption risks in aid-funded public procurement.

\section{How Does Recipient Country Political Economy Affect Corruption?}

To characterize recipient-country political economy contexts, we follow prior literature (Kelsall 2013; Khan 2010; Rock and Bonnett 2004) in focusing on two key dimensions: (i) party system institutionalization (PSI), defined as the degree of "stability in who the main parties are and in how they behave" (Mainwaring 1998), and (ii) state capacity, defined as the state's ability "to implement official goals, especially over the actual or potential opposition of powerful social groups" (Skocpol 1985: 9). While the first dimension shapes elites' time horizons (time horizons become longer as PSI increases), the second captures elites' capacity to enforce anti-corruption laws at all levels of government.

Public procurement typically accounts for $50 \%$ or more of government spending in the developing world (World Bank 2015a), making it a key target for elites seeking to steal (Ware et al. 2007; Søreide 2002). Technically, it is controlled by bureaucrats rather than politicians, but politicians are often able to exert considerable influence through control over appointments to the bureaucracy and regulatory agencies (DávidBarrett and Fazekas 2019). Regulatory bodies typically lack the independence to challenge political interference, while aggrieved losing bidders refrain from making complaints for fear that it will prejudice their chances of winning future contracts. Thus, political elites can certainly influence the procurement process, and the incentives and opportunities they face are at the centre of our theoretical framework.

Political parties play a particularly important role in determining political elites' time horizons - and thereby incentives to engage in corruption. Certainly, there are other factors that shape elites' time horizons. Our decision to focus on the degree of PSI was motivated by a growing body of political economy work that shows that the strength of political parties - through the time horizon mechanism-plays an important role in

\footnotetext{
$\overline{{ }^{2} \text { We lack sufficiently detailed }}$ data to differentiate between impacts on corruption risks due to competition or scrutiny.
} 
explaining differences in the quality of governance. Crucially, studies have shown that PSI matters both in democratic and non-democratic regimes (e.g. Bizzarro et al. 2018; Rasmussen and Knutsen 2017; Kuhonta 2011). In other words, scholars of governance are beginning to understand that PSI - compared to other institutional factors, such as electoral systems or the distinction between parliamentary and presidential systems of government - spans a much wider spectrum of political regimes, ranging from multiparty democracies (such as Denmark) to single-party totalitarian systems (such as China). In autocratic regimes, dictators who can rely on a highly institutionalized party generally sustain themselves in power for longer than dictators who only have a weakly institutionalized party at their disposal. In democratic regimes, more strongly institutionalized party systems lengthen politicians' time horizons by providing certainty of party survival and stability in electoral returns.

We also identify other mechanisms through which stability in party strength and behaviour affect the extent of corruption. First, the most efficient way for a strongly institutionalized party to maintain a large support base is to "buy" electoral loyalty with public goods (such as economic growth) rather than clientelist goods (Bueno de Mesquita et al. 2003; Haber 2006). Second, in highly institutionalized party systems - where political parties usually have high longevity - citizens can more easily attribute responsibility for government mismanagement and corruption to political parties (Schleiter and Voznaya 2016; Tavits 2007). Third, strongly institutionalized parties curb corruption through the provision of stable and clearly identifiable career paths. Specifically, strong parties can promote norms that reward non-corrupt behaviour through political career advancement. ${ }^{3}$

In the absence of theories on how corrupt elites optimise between stealing from development aid-funded contracts as opposed to publicly funded procurement contracts, we assume that PSI exerts a homogenous effect on both types of public spending. This assumption seems reasonable given that aid is spent through national procurement systems in the same way as domestic budget funds; moreover, we analyse World Bank loans, rather than grants, which are perceived as more similar since they have to be paid back. Hence, we hypothesise:

$\mathrm{H} 2$ : Higher party system institutionalization is associated with lower corruption risks in aid-funded public procurement.

While we expect PSI to shape elites' incentives to engage (or not) in corruption, we also acknowledge that, when elites are incentivised to curb corruption in the spending of aid, they can only do so if they have the means to enforce anti-corruption regulations across procuring bodies - i.e. state capacity. We thus follow Khan (2010: 65) who argues that national elites can only prevent lower-level factions from engaging in rentseeking behaviour when they enjoy greater "implementation and enforcement capacities" than the latter. Applied to our analysis of the aid-corruption link, assuming that World Bank-funded procurement behaves similarly to national procurement, we arrive at the following hypothesis:

\footnotetext{
${ }^{3}$ For example, academic work on the Chinese Communist Party regularly highlights how the national leadership uses personnel management to create disincentives for corruption at the cadre level (Landry 2003).
} 
H3: Higher state capacity is associated with lower corruption risks in aid-funded public procurement.

We acknowledge that corruption is itself a factor that can undermine the state's ability to implement policies: the extent of corruption may feed into the measure of state capacity. However, corruption is merely one factor in the complex theoretical framework that underpins the concept of state capacity. Other factors that may weaken or strengthen capacity include the state's revenue streams, the quality of bureaucratic staff, the state's social embedding and the international context (Migdal 1988; Bräutigam 2008).

\section{Interactions: Donor Regulatory Change Meets Recipient-Country Political Economy}

So far, we have argued that the impact of aid on corruption depends, on the one hand, on donor corruption control regulations, and on the other hand, on recipient-country political economy in terms of PSI and state capacity. Further, we propose that these two sets of factors interact. This argument draws on literature about the importance of "thinking and working politically" when disbursing development aid (Rocha Menocal 2014). Attention to the political economy of a country is increasingly regarded as vital to the effectiveness of aid programmes and underpins new problem-driven iterative approaches (Andrews et al. 2012; Carothers \& de Gramont 2013; Grindle 2007).

In our case, political economy factors may mitigate the impact of increased oversight and wider access to tenders, by either increasing or decreasing their effectiveness as anticorruption instruments. As discussed, weakly institutionalized parties allow political elites to evade responsibility for corrupt behaviour. This applies not only to elites' relationships with citizens but also to their exchanges with donors. That is, donor regulatory reforms that are aimed at increasing the risks that come with engaging in corrupt acts may only work in contexts of high PSI where donors are able to hold domestic elites responsible. Moreover, strongly institutionalized parties are an "organisational weapon" when it comes to enforcing new institutional rules and policies. Most importantly, they "back reforms with organisational power, sustain policy continuity, maintain dialogue with the grass roots [and] monitor the bureaucracy's implementation of policy" (Kuhonta 2011). In our case, they offer a vehicle for the implementation of donor anti-corruption tools against potential veto players. This means that elites in political systems with strong parties not only face incentives to implement donors' anti-corruption interventions but also control the organisational means to do so. On the other hand, if elites perceive the risks and costs of additional externally imposed rules to be small, they may use this organisational capacity to circumvent new rules, thus weakening the reform's impact. In the absence of conclusive theoretical guidance as to which mechanisms are stronger, we put forward the following hypothesis:

H4: Increased donor oversight and wider access to tenders decrease corruption risks most where party system institutionalization is high.

Domestic state capacity can mitigate the impact of donor regulatory changes through three major channels. In high-state-capacity recipient countries, the gap between the regulation imposed by donors and that required by the domestic public procurement systems is 
considerably narrower, in many cases negligible. For example, there may already be a widely-used e-procurement and electronic tender advertisement system in place, hence, donors' requirements to use such tools do not change much. The World Bank's use of assessments of domestic state capacity to select contracts for prior review (enhanced oversight) implies that, in high state-capacity recipient countries, the new rules are expected to have a lesser impact. However, high state-capacity public administrations tend to have greater professional expertise regarding public procurement rules and tendering processes. Hence, if corrupt elites intend to comply with the new rules but nevertheless strategically use alternative techniques to engage in corruption, the amount of corruption might be unchanged, even though the underlying patterns are different. This is evidenced by the fact that, in a range of high-state capacity countries with advanced e-procurement systems like the UK, Sweden and the Czech Republic, extensive corruption in procurement still occurs (Broms et al. 2017). These mechanisms point towards the same hypothesis:

H5: Increased donor oversight and wider access to tenders decrease corruption risks least where state capacity is high.

\section{Methods, Data, and Indicators}

\section{Methods}

We test our hypotheses on the November 2003 update to World Bank procurement rules. This case has wider applicability because the World Bank is one of the largest multilateral providers of developmental aid and other donors followed its reforms later, and because the 2003 reform was closely designed on the economic models of anticorruption outlined above. The 2003 reform significantly increased donor oversight through several requirements: the introduction of procurement plans (to which buyers can be better held to account), obligatory prior review mechanisms for cases where all bids are rejected (to check that reasons for rejecting bids were legitimate), new definitions of corruption and fraud (to clarify what would count as misconduct) and the extension of oversight to bidders (through audit requirements). The reform also sought to improve bidder access to the market by requiring greater use of both electronic advertisement and e-procurement methods.

We employ a quantitative research design which exploits the distinct break in the application of the new rules to World Bank-financed projects, and the time lag in issuing tenders and awarding contracts in control and treatment projects (projects governed by the old and new rules, respectively). Because World Bank projects tend to take several years to complete, on average 5.6 years with standard deviation of 2.6 years, our control and treatment samples overlap for several years providing a sufficient number of observations. Using propensity score matching, we match contracts according to similarities in country, year, market, buyer organisation and contract value ${ }^{4}$ such that matched pairs differ only by the regulatory regime governing their

\footnotetext{
${ }^{4}$ Please note that propensity score matching incorporates categorical variables such as sector as a set of dummy variables while the eventual matching makes use of the propensity score itself rather than exact matching by category.
} 
projects, allowing us to approximate the causal impact of the intervention. Given the breadth of our data, we achieve a high-quality matching across the control and treatment groups (goodness of fit statistics for the most complete, preferred matching are in Appendix Figs. 9, 10 and Table 8). For the years following the 2003 regulatory change, the matching estimation exploits the fact that the same or very similar countries, buyers and markets see similar contracts awarded from projects which are either treated or not depending on the project approval date (see Fig. 1). Such a strategy accounts for a host of country and local-level institutional factors as well as marketlevel variables such as size and maturity which would confound causal identification. We find the matching based on average corruption risks (our dependent variable) prior to the intervention on the country as well as procuring entity levels particularly powerful. These control variables are superior to traditional confounding factors controlled for in the literature such as ethnic fractionalisation or democracy because they are much more fine-grained and use variables more directly relevant for causal identification at the contract level. We also carry out traditional binary logistic regressions on the entire 2000-08 period controlling for country, continent, year, economic sector and log contract value. While these regressions are arguably less appropriate for identifying causal impacts, they allow for a detailed exploration of the impact of state capacity and PSI, and the interactions between these variables and the intervention.

A potential weakness of our identification strategy is that there might be gaming around the temporal cut-off, i.e. project approval dates are not brought forward artificially to avoid using the new regulatory regime. However, we think this is not happening because the date at which the new rules apply is globally imposed by the World Bank which means it is quasi-independent of individual projects. Moreover,

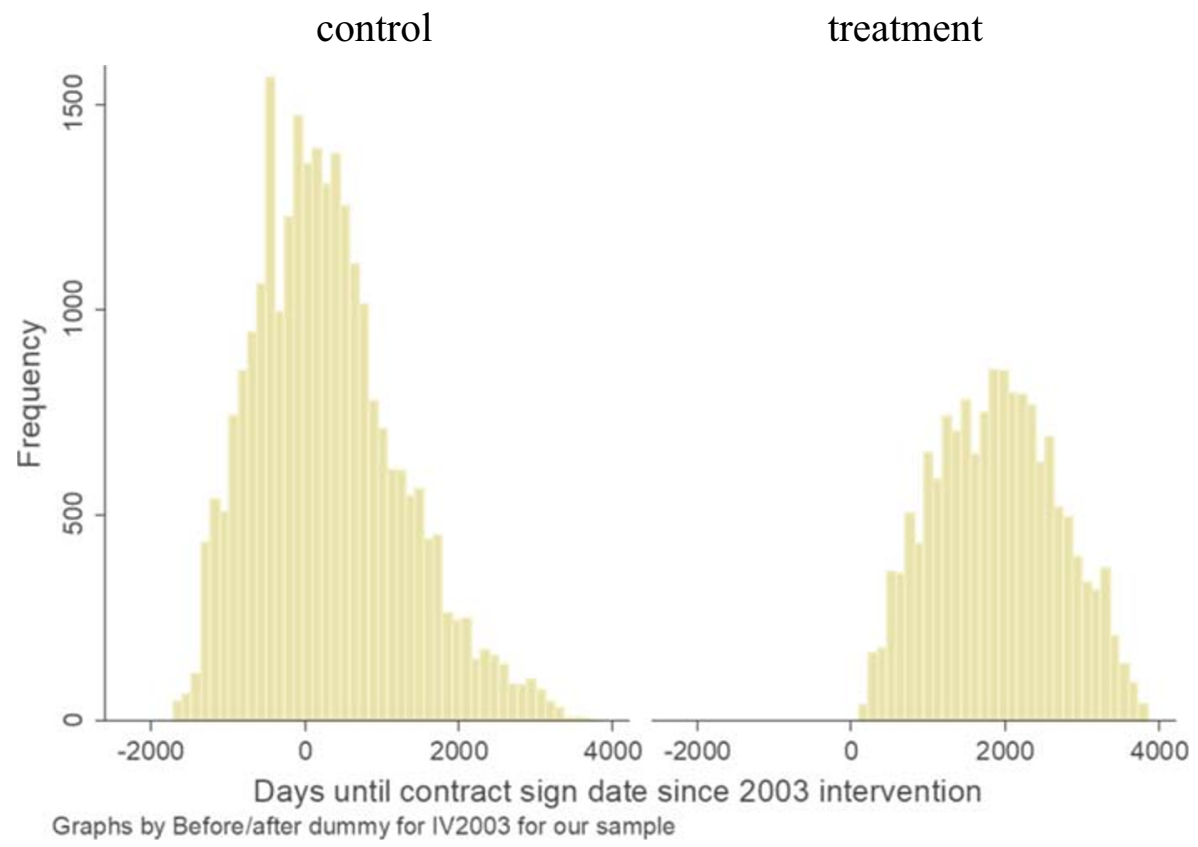

Fig. 1 Frequency distribution of control and treatment contracts according to the time elapsed since the 2003 intervention, World Bank, Goods, works and services 
designing, negotiating and approving individual projects are a lengthy exercise with many actors involved both at the World Bank and in national governments, leading to uncertainties about project start dates, which makes gaming hard in practice. These arguments are also supported by statistical tests of observed project distributions around the cut-off date (see Appendix Figs. 7 and 8).

To understand the nature of the World Bank controls on procurement, we undertook a comprehensive qualitative coding of the World Bank's procurement guidelines for goods, works and services. The coding frame was theoretically underpinned by economic models of corruption control, distinguishing between interventions which seek to constrain opportunities for corruption on the public official (buyer) side and those which target behavioural change on the part of suppliers, aimed at improving competition. This allowed us to make predictions about how the change in the rules might affect behaviour and hence be observable in our corruption risk indicators. Coding was completed by conducting in-depth year-on-year comparison of guidelines to ascertain changes, making it possible to track year-on-year changes to the rules. From this, a narrative account was developed where major changes were highlighted and compared, to identify key themes. Interviews were also carried out with staff from the World Bank procurement team and some country offices to clarify what various interventions aimed to achieve and how they were implemented in practice.

\section{Data}

Our database contains all major contract awards of World Bank-financed projects for the fiscal years $1998-2013,{ }^{5}$ that is, all "prior-reviewed" contracts. These are contracts awarded in tendering processes that have been reviewed by the World Bank before they were awarded and at key stages throughout the project cycle. Only contracts with an estimated value above a certain context-specific threshold undergo the prior-review process. ${ }^{6}$ (Tendering processes for other contracts, the so-called post-reviewed tenders, are managed completely by the recipients of World Bank loans, with World Bank staff reviewing and auditing projects only after the end of the loan contract.) Thresholds for prior review are set in a complex process and are reviewed regularly. The World Bank first decides to what degree a recipient country can be trusted to manage aid funded procurement on its own through the Country Procurement Assessment Review (CPAR). ${ }^{7}$ Based on this assessment of the risks associated with the sector, the implementing agency and the procurement method, a project risk level-or review threshold - is established. The World Bank provides an indicative list of thresholds for each country, but the risk assessment is outlined and the exact thresholds determined only in procurement plans, which are subject to the World Bank's "no objection" scrutiny at key stages throughout.

As our dataset only contains high-risk tenders which undergo greater World Bank oversight and control, our findings are not representative of all aid spending financed by the World Bank, but only that part where risks are higher (and hence this greater

\footnotetext{
${ }^{5}$ A fiscal year begins in July and ends in June, so we observe each major contract award between July 1997 and June 2014.

${ }^{6}$ See Appendix A of World Bank Procurement Guidelines: http://bit.ly/2wuj2a9.

${ }^{7}$ Details of how the bank assesses projects: http://bit.ly/2wa6Qc1.
} 
degree of control is deemed necessary). For other World Bank-financed procurement tenders, we assume that donor corruption controls are of lesser importance as oversight is more light touch — and risks are lower, at least in principle.

Prior-review contracts represent a significant, albeit fluctuating, share of total lending (see Fig. 2). ${ }^{8}$ This fluctuation is due to the constantly changing country, sector and organisational composition of spending, as well as project start and completion dates. While we cannot fully rule out sample biases such as gaming of prior review thresholds for bureaucratic cost avoidance reasons, our interviews and review of procedures (e.g. number and range of people required to approve changes in thresholds) suggest that any gaming is likely to be of minor importance.

We compiled a dataset by scraping and downloading data directly from the World Bank's public website (for a full description of data sources, see Appendix A). We also used an internal World Bank database which includes a slightly richer set of variables, allowing us to construct our dependent variable indicating corruption risk: whether a contract was awarded in a tender which received only one bidder, hereafter "single bidding". This variable is only available for contracts awarded in 1998-2008. ${ }^{9}$

We focus on changes introduced by the November 2003 change to the rules for tenders of goods, works and services. The new rules apply to projects where the project concept note is approved after the new rules became effective; the regulations to follow are specified in the financial agreement in each project. For projects approved prior to the introduction of the new rules, contracts continue to be awarded according to the old regulatory regime. Although in theory the borrower may request a switch to the new rules in an already ongoing project and the Bank may agree, the World Bank procurement expert we interviewed told us that, "Most Borrowers and Bank staff would rather not go through a formal restructuring if the only modification is the change of procurement rules" (email correspondence with World Bank procurement specialist, 18 May 2017). Thus, in the majority of cases, projects follow new regulations only if the project approval date is later than the effective date of the new rules. This means that tendering processes that occur at the same time may operate under different regulations, depending on whether their project's approval date is before or after the effective date of the new regulation. This is critical to our identification strategy, and hence we have fully investigated the possible exceptions. A possible concern is whether the new or old regulations are applied when additional financing takes place (i.e. project extension), which occurs for about $25 \%$ of projects. Although the new regulations apply by default, most borrowers request to remain with the old rules to enable a smooth continuation of ongoing projects and the Bank has approved these requests in all cases (email correspondence with World Bank procurement specialist, 18 May 2017).

In Table 1, the number of contracts in the control and treatment group is summarized on a yearly basis, where the control group consists of projects approved before 1 November 2003 and the treatment group consists of projects approved after. We only

\footnotetext{
${ }^{8}$ Please note that only about $70 \%$ of World Bank lending goes into funding projects, with the rest providing direct budget support or Development Policy Financing. The latter falls outside the interest of this article as it does not lead to procurement contracts regulated by World Bank policies (World Bank 2015b).

9 The full dataset is downloadable at http://www.govtransparency.eu/index.php/category/databases/.
} 


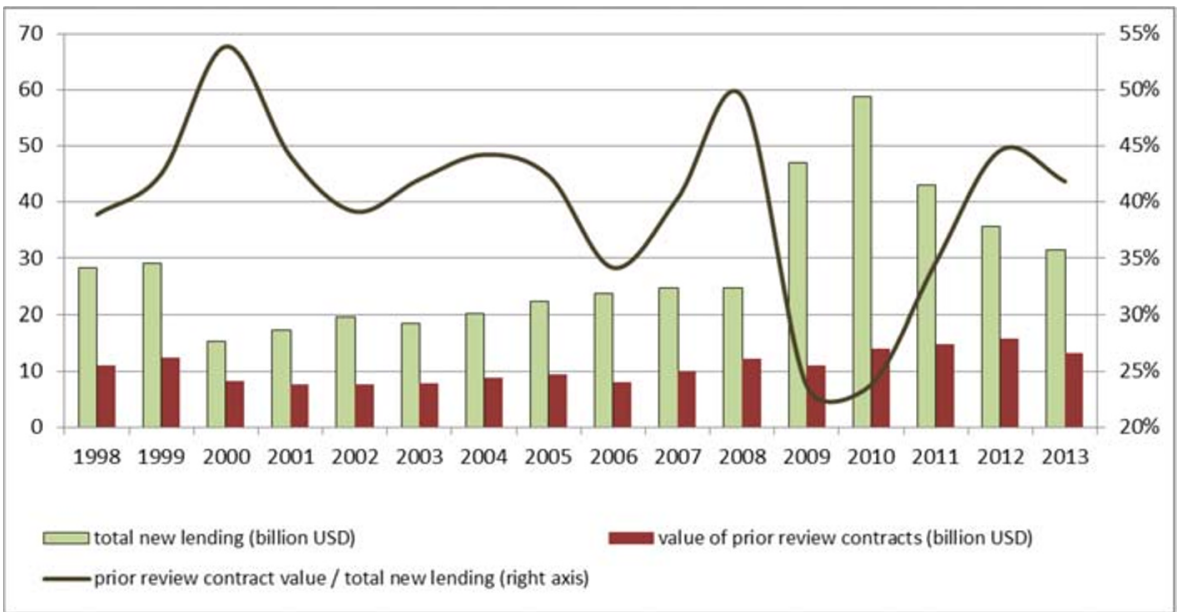

Fig. 2 Share of prior review contracts compared to total new lending by the World Bank (1998-2013). Source: Own calculation based on World Bank data

consider contracts larger than 25,000 USD to exclude small contracts where competition is less likely to happen.

\section{Indicators}

One of our innovations is the identification of an objective proxy indicator of corruption in aid-funded public procurement as our dependent variable. The indicator is based on a methodology widely applied to national public procurement datasets to identify corruption risks (Klasnja 2016; Charron et al. 2017) and contributes to a growing number of objective corruption indicators based on administrative data (Escresa and Picci 2016; Cordis and Milyo 2016; Escresa and Picci 2015). Note that indicators of corruption risk cannot be used to determine whether corruption occurred in a given instance, but rather indicate an aspect of the process or an outcome which likely reflects underlying corruption - but could also be explained by other reasons.

Public procurement is assumed to be least prone to corruption where the process is open and competitive, and procurement regulation sets a number of maxims intended to ensure openness. Where the process deviates from these maxims, this may indicate a deliberate manipulation by a corrupt public official (or network of

Table 1 Number of contracts awarded in treatment and control groups, contracts above 25,000 USD, goods and works, 2000-08

\begin{tabular}{lllllllllll}
\hline \multicolumn{1}{c}{ Contract award year } \\
\cline { 2 - 10 } & 2000 & 2001 & 2002 & 2003 & 2004 & 2005 & 2006 & 2007 & 2008 & Total \\
\hline Control & 1307 & 2437 & 3573 & 4082 & 4077 & 3494 & 2219 & 1747 & 1216 & 24,152 \\
Treated & 0 & 0 & 0 & 0 & 321 & 1157 & 1641 & 2164 & 2266 & 7549 \\
Total & 1307 & 2437 & 3573 & 4082 & 4398 & 4651 & 3860 & 3911 & 3482 & 31,701 \\
\hline
\end{tabular}


public and private actors) to favour a particular company and gain a private advantage. The outcomes of the public procurement process serve as the best indicators of corruption risk (Kenny and Musatova 2010). In particular, where only one company submitted a bid even though the process should have been open to competition, international or domestic, the risk of corruption is particularly high. A single bid thus serves as our prime dependent variable.

Single bidding does not prove that corruption occurred, but it is an indicator of corruption risk, which - when analysed in the context of large datasets - can point to overall patterns that warrant investigation or a policy response. While the presence of a single bid may, in some circumstances, be entirely consistent with a fair and open tender (e.g. where markets are underdeveloped or the requirement is for a specialist product or service), when observed as a pattern in a large dataset, it indicates a risk that this outcome results from corrupt manipulations of the procurement process. As long as market conditions predict healthy competition, and World Bank public procurement regulations assume that development aid-funded tenders are competitive in principle, ${ }^{10}$ single bidding can be regarded as indicative of corruption (rather than immature markets or low administrative capacity). Statistical evidence of the validity of single bidding as a corruption proxy is in Appendix Table 4 and Fig. $6 .{ }^{11}$ Since expectations of open and fair competition are especially high in some tendering procedure typesinternational competitive bidding and national competitive bidding - we repeat our analysis on a sample restricted to these procedures, obtaining consistent results (Appendix Tables 8 and 9).

Hypotheses 1, 4 and 5 employ the November 2003 regulatory change as the main dependent variable. This indicator is defined as a $0-1$ binary variable taking the value of 0 if the project concept note approval date was before this date (control group) and 1 if it was after (treatment group). As there were other regulatory changes both before and after the 2003 change, we restricted the treatment and control groups to projects approved between January 1999 and September 2006, inclusive.

To operationalise the independent variables in hypotheses 2-5 (recipient-country political economy), we make use of two widely used cross-country indicators: (i) VDem's PSI (v2xps_party of V-Dem) and (ii) Hanson and Sigman's (2013) state capacity indicator.

The PSI score is composed of six indicators from the V-Dem dataset, with party strength measured as the extent to which parties have: (1) permanent national party organisations, (2) permanent local party branches, (3) centralized mechanisms of candidate selection, (4) legislative cohesion, (5) minimal party switching and (6) programmatic (rather than clientelist) linkages to their social base. Indicators are aggregated through simple addition.

The state capacity variable is constructed from 20 indicators, using Bayesian latent variable analysis. The indicators represent three core dimensions of state capacity: extractive (the ability to collect information and taxes from their populations), coercive

\footnotetext{
${ }^{10}$ Please note that we exclude consultancy contracts from the analysis as those are often less competitive by nature due to specific and sometimes rare skills purchased.

${ }^{11}$ Single bidding in competitive tenders, nevertheless, only captures one particular form of high-level corruption closely aligned with closed access and institutionalized corrupt relationships between public and private elites. There are other types of corruption where competition occurs among oligarchic groups, with multiple firms competing on official tendering criteria as well as bribes.
} 
(the ability to preserve borders and protect against external threats) and administrative (the ability to efficiently create public goods and regulate economic activity). The indicators are measured using a combination of state outputs (e.g. tax revenue, frequency of population censuses), infrastructural properties (e.g. military personnel per capita) and survey data - both expert surveys (e.g. ICRG Bureaucratic Quality) and citizen surveys (e.g. civil service confidence from the World Values Survey). ${ }^{12}$ Hanson and Sigman's dataset offers the best standardized state capacity measure available for a long enough time period for our country sample (1960-2010). Descriptive statistics of all variables are in Appendix Tables 6 and 7.

\section{Results}

\section{Main Effect of the Intervention}

We carried out four comparisons of the treatment and control groups to determine the impact of the intervention on the share of single-bidder tenders, each leading to the same substantive conclusion with only minor variation in effect sizes (Table 2). Our initial analysis, a raw comparison without matching, suggests that the intervention did curb corruption risks, leading to a 3.6 percentage point decrease in share of single bidding. However, as the two samples are rather uneven on several dimensions, we also implemented three different propensity score matching exercises with gradually increasing covariate sets, at the expense of shrinking the sample sizes (matching 1-3 in Table 2).

The first matching exercise balanced the two groups according to log contract value, contract's main sector, buyer's country and World Bank global region and year of contract award. In the second, corruption risk (single bidder \%) prior to the intervention - on the country and buyer levels - was added to matching covariates (previous country and continent covariates were removed to avoid overrepresentation of country characteristics in the matching). The third method also matched on countrylevel state capacity and PSI (goodness of fit statistics for the most complete, preferred matching are in Appendix Figs. 9, 10, and Table 8).

In all the matching exercises, the impact of the intervention was consistently negative and significant, with the magnitude ranging between -3.6 and -4.3 percentage points. In addition, binary logistic regressions deliver very similar results: the average marginal effect of the intervention ranges between -2.8 and -3.8 percentage points (Table 3 ). Robustness tests on a sample restricted to competitive procedures can be found in Appendix Tables 8 and 9, with substantially the same conclusions and somewhat larger effect sizes. Hence, we find strong and consistent support for H1, demonstrating that strengthening oversight, increasing publicity requirements and lowering transaction costs through e-procurement in World Bank-funded public procurement of goods and works decreased corruption risks.

\footnotetext{
${ }^{12}$ We applied a broad measure of state capacity, incorporating a variety of functions of the modern state, because we believe that each of these functions is related to public agencies' ability to combat corruption. For example, higher extractive capacity - in particular, in terms of tax collection - means that, at least in principle, there are more funds available for anti-corruption programmes. Similarly, only when the police and military are equipped with strong coercive power, will the state be able to enforce anti-corruption laws across the entirety of its territory.
} 
Table 2 Simple and matched comparisons of treatment and control groups, single bidder \%, contracts above 25,000 USD, goods and works, 2003-08

\begin{tabular}{lclll}
\hline & Raw comparison & Matching (1) & Matching (2) & Matching (3) \\
\hline Control & $21.7 \%$ & $22.1 \%$ & $22.4 \%$ & $22.8 \%$ \\
Treatment & $18.2 \%$ & $17.9 \%$ & $18.7 \%$ & $18.5 \%$ \\
Diff (treatment-control) & $-\mathbf{3 . 6 \%} * * *$ & $-\mathbf{4 . 2 \%}$ **** & $-\mathbf{3 . 7 \%}$ & $-\mathbf{4 . 3 \%} * *$ \\
$95 \%$ c. interval: lower bound & $-4.8 \%$ & $-5.7 \%$ & $-6.7 \%$ & $-7.3 \%$ \\
$95 \%$ c. interval: upper bound & $-2.3 \%$ & $-2.7 \%$ & $-0.7 \%$ & $-1.3 \%$ \\
$N$ control & 12,610 & 5358 & 1404 & 1375 \\
$N$ treatment & 5778 & 5358 & 1404 & 1375 \\
Matching variables & & & & \\
Log contract value & & $\mathrm{Y}$ & $\mathrm{Y}$ & $\mathrm{Y}$ \\
Main sector & $\mathrm{Y}$ & $\mathrm{Y}$ & $\mathrm{Y}$ \\
Country & $\mathrm{Y}$ & & $\mathrm{Y}$ \\
Year & $\mathrm{Y}$ & $\mathrm{Y}$ & $\mathrm{Y}$ \\
Country prior single bidder \% & & & $\mathrm{Y}$ & $\mathrm{Y}$ \\
Buyer prior single bidder \% & & & $\mathrm{Y}$ & $\mathrm{Y}$ \\
Country capacity & & & \\
Country PSI & & & & \\
\hline
\end{tabular}

Significance levels: $* * *<0.1 \%, * *<1 \%, *<5 \%$

\section{Party System Institutionalization and State Capacity}

After establishing the overall effect of the November 2003 intervention, we turn to the independent effects of PSI and state capacity (H2 and H3). On the most basic bivariate level, contracts awarded in single-bidder tenders tend to be located in countries with lower state capacity as well as lower PSI (Fig. 3).

Both differences between single- and multiple bidder-contracts are statistically significant and substantial: in our data, an increase in PSI score from -0.10 to 0.04 is equivalent to moving from Uganda to Moldova, while a change from a state capacity score of -0.42 to -0.24 is roughly the equivalent of moving from Kenya to Georgia.

These simple bivariate relationships are confirmed by binary logistic regressions controlling for a range of country and contract characteristics already used in the matching estimation above: log contract value, contract's main sector, buyer's country and year of contract award (Table 3). A one-unit increase in PSI (1.2 standard deviation) decreases single bidding by 4.7 percentage points in model 2 on average (significant at $10 \%$ level); while a one-unit increase in state capacity (1.5 standard deviation in our sample) decreases single bidder prevalence by 4.4 percentage points in model 3 on average. All this evidence points at the validity of $\mathrm{H} 2$ and $\mathrm{H} 3$ (for additional robustness tests see Appendix Tables 8 and 9). However, the empirical evidence presented is only correlational, albeit backed-up by a strong theoretical literature. In the absence of high impact and discrete policy changes, we are unable to precisely identify the causal effects. This reflects the fact that both PSI and state capacity change only very slowly within a given country (Rueschemeyer 2005; Hicken and Martinez Kuhonta 2011). 
Table 3 Binary logistic regressions explaining single-bidder contracts, contracts above 25,000 USD, goods and works, 2004-07+ (log-odds coefficients and $p$ values are reported)

Model

Single-bidder dummy

2003 GWS intervention

Party system institutionalization

State capacity

2003 GWS intervention $=1$ \# State capacity

2003 GWS intervention = 1 \# Party system institutionalization

$\begin{array}{lllll}-0.173^{* *} & -0.221^{* * *} & -0.263^{* * *} & -0.172^{* *} & -0.122 \\ (0.005) & (0.000) & (0.000) & (0.006) & (0.085) \\ & -0.332 & & 0.115 & \\ & (0.093) & & (0.777) & \end{array}$

(0.093)

$-0.310^{*}$

$-0.786^{* * *}$

(0.010)

(0.000)

$0.261^{* * *}$

(0.009)

0.0502

(0.462)

Control variables

Log contract value

Main sector

Country

Year

Constant

Observations

$R^{2}$

$\begin{array}{lllll}\mathrm{Y} & \mathrm{Y} & \mathrm{Y} & \mathrm{Y} & \mathrm{Y} \\ \mathrm{Y} & \mathrm{Y} & \mathrm{Y} & \mathrm{Y} & \mathrm{Y} \\ \mathrm{Y} & \mathrm{Y} & \mathrm{Y} & \mathrm{Y} & \mathrm{Y} \\ \mathrm{Y} & \mathrm{Y} & \mathrm{Y} & \mathrm{Y} & \mathrm{Y} \\ \mathrm{Y} & \mathrm{Y} & \mathrm{Y} & \mathrm{Y} & \mathrm{Y} \\ 15,476 & 24,854 & 24,380 & 15,151 & 14,879 \\ 0.195 & 0.172 & 0.171 & 0.198 & 0.197\end{array}$

Significance levels: $* * *<0.1 \%, * *<1 \%, *<5 \%$

Note: Standard statistical significance levels reported. As full population data is used rather than a random sample, adequate significance levels can be obtained using Monte Carlo random permutation simulations (Good 2006). For every regression, simulated significance levels are comparable to standard significance levels, leading to the same conclusions in each case

+ In models 2 and 3, the time period is longer: 2001-07 encompassing the pre-treatment period too. This is because the relevant hypotheses are not directly about the treatment but the country-level factors: party system institutionalization and state capacity. Both of these factors change slowly over time, so longer time series deliver more reliable estimates

\section{Interaction Effects}

Using the binary logistic set-up described above, we find that PSI does not mitigate the effect of the intervention, contrary to our expectations (H4) (model 4 in Table 3). However, the interaction effect between state capacity and the 2003 intervention is positive and significant in model 5 (Table 3). Hence, we find evidence supporting H5 - the 2003 intervention predominantly had an effect in countries with low-state capacity, while the effect is insignificant in high-capacity countries (Fig. 4 and Fig. 5). While propensity score matching is less amenable to tracking interaction effects, as a robustness test we include matching specifically for high and low PSI and state capacity, with essentially the same conclusions (Appendix Figs. 11 and 12). As the regression model in Table 3 controls for time invariant country characteristics (country fixed effects) such as general corruption level and the matching estimator in Appendix 


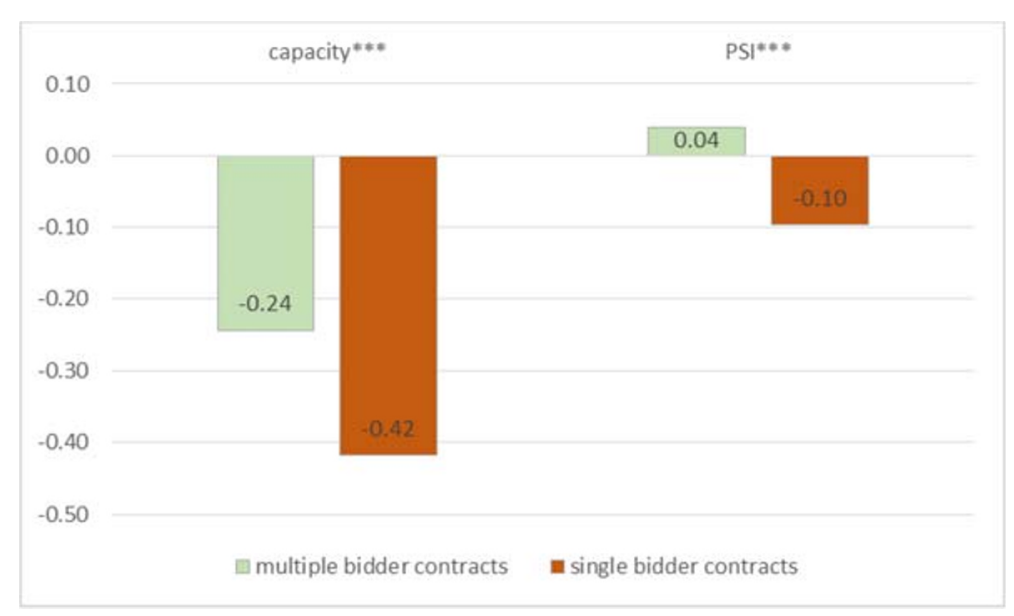

Fig. 3 Simple comparisons of single- and multiple-bidder contracts according to country average state capacity and PSI, contracts above 25,000 USD, goods and works, 2000-08. Significance levels: $* * *<$ $0.1 \%, * *<1 \%, *<5 \%$

(Fig. 11) balances starting corruption levels at the organisation level, we can rule out the interpretation that the higher observed effect of the intervention in low-statecapacity countries is due to initial differences in corruption levels. Due to our innovative empirical strategy, we can isolate the two impacts independently as well as their joint effect. Robustness tests on a sample restricted to competitive procedures are in Appendix Tables 8 and 9, with substantially the same conclusions.

\section{Discussion and Conclusions}

Taking a 2003 World Bank reform of procurement rules as a case study, we find that donor efforts to control corruption in aid spending through national

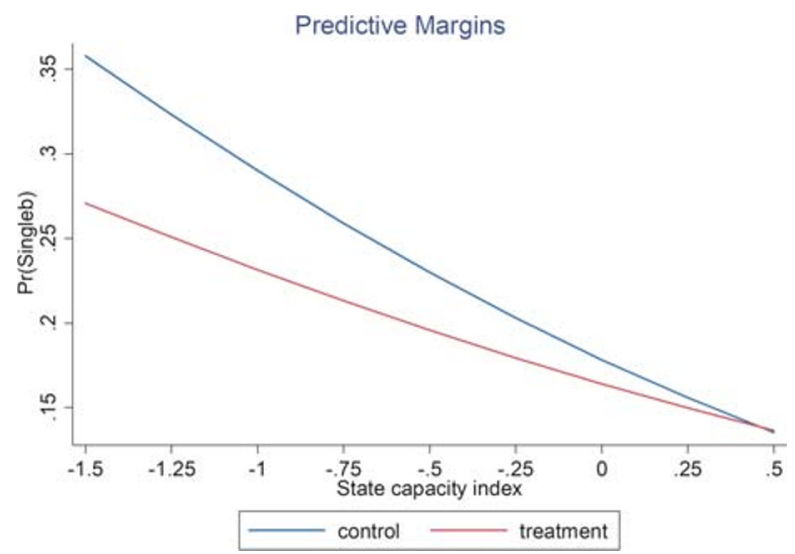

Fig. 4 Predicted single-bidder ratio as a function of state capacity and the 2003 intervention, contracts above 25,000 USD, goods and works, 2004-07 


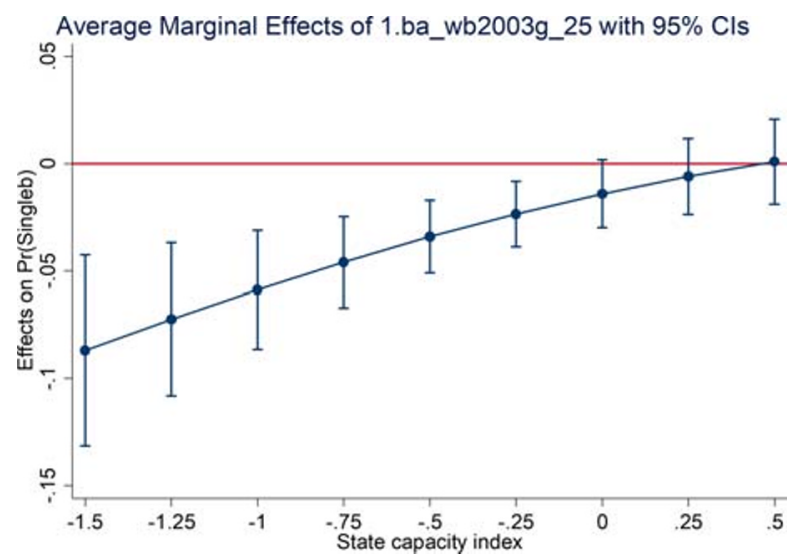

Fig. 5 Average marginal effects of the 2003 intervention as a function of state capacity, contracts above 25,000 USD, goods and works, 2004-07. Note: the red zero line shows the value at which the coefficient becomes insignificant

procurement systems, by tightening oversight and increasing market openness, were effective in reducing corruption risks. This suggests that theories of corruption control based on reducing opportunities and increasing constraints on the power of public administrators have merit. We also find support for our hypotheses that the political context in recipient countries affects corruption risks in aid. In countries with high PSI, a proxy for elites having longer time horizons, the prevalence of single bidding is lower. The same is true for countries with greater state capacity. Taken together, these findings strengthen previous studies, which we reviewed at the beginning of the paper (e.g. Kelsall 2013; Khan 2010; Rock and Bonnett 2004), that argue for the importance of a two-dimensional framework to understand the prevalence of corruption: elites' time horizons (which we measure using the indicator of PSI) and their ability to enforce anti-corruption regulations (measured by the indicator of state capacity).

When looking at the interactions between the reform package and the recipient country political context, we find that the effect of increased oversight and wider access to tenders in reducing corruption is larger in countries with low-state capacity. This may reflect several causal mechanisms. First, in countries with low state capacity, donor controls effectively substitute for weaknesses in state control over funds by increasing oversight. This helps to ensure that aid reaches the right destinations (although it may have negative implications in the long term, since it does not allow local institutions to build up capacity to monitor and control funds themselves). Second, countries with low state capacity typically have less technologically advanced procurement systems (e.g. paper-based tender submission), hence increasing the use of electronic submission is likely to widen access to tenders in particular in such countries. Third, in lowstate capacity countries, national elites may lack the capacity to control corruption in some parts of their bureaucracies. Under such a scenario, increasing World Bank oversight and use of e-procurement tools would strengthen elites' own capacity to limit bureaucratic corruption and pursue economic growth. 
We find no evidence that higher levels of PSI amplify the effect of the reform. This may suggest that the mechanisms pulling the interaction effect in opposite directions cancel each other out. Less institutionalized parties may more readily evade responsibility for corruption and hence respond less to increased oversight, but more institutionalized parties may be better able to strategically circumvent efforts to increase donor oversight. To explain this dual character of PSI, consider two cases of successful late industrialisation: South Korea and Malaysia. After World War II, political power became highly centralised in both countries - under a military regime in South Korea and a dominant-party dictatorship in Malaysia. In these cases, long time horizons incentivised elites to invest in economic development and industrialisation. However, dramatic growth in the 1960s and 1970s co-existed with systemic political corruption, which was a key source of income for the respective regime parties, the Democratic Republican Party (DRP) and the United Malays National Organisation (UMNO). Crucially for our discussion, a common way to organise corruption in these countries was through the mechanism of non-competitive resource allocation: in South Korea, the DRP allocated public loans to selected companies in exchange for large bribes (Kang 2002; Wedeman 1997), while in Malaysia the government regularly funnelled public contracts to UMNO-owned enterprises to bolster the party (Gomez and Jomo 1999; Khan 1998).

These cases tell us two things. First, corruption organised through single bidding is not necessarily incompatible with economic growth. Elites in institutionalized party systems and with long time horizons might work towards growing the economy while at the same time engaging in corruption through manipulation of procurement. Second, corrupt forms of single bidding can be an important source of funding for institutionalized parties - both in authoritarian regimes and in democratic political systems. Thus, party elites in recipient countries may face disincentives to implement donors' anti-corruption regulations, as their political survival depends on funds that they gain through uncompetitive bidding processes.

\section{Appendix A Description of datasets}

Major contract awards https://finances.worldbank.org/Procurement/Major-ContractAwards/kdui-wcs3

Contains "prior-reviewed" contracts by World Bank i.e. the contract award commitments that were reviewed by the World Bank before they were awarded. Each contract is being prior-reviewed in case their value is above a certain threshold. Thresholds vary by country and the type of contract (goods, works, services) and are defined in the procurement plans.

World Bank Projects and Operations http://data.worldbank.org/data-catalog/projectsportfolio 
Includes basic information of all World Bank projects, such as the project title, task manager, country, project id, sector, commitment amount and financing. It also provides links to publicly disclosed online documents.

Notices and Contracts (WB website) http://projects.worldbank. org/procurement/procurementsearch?lang=en\&srce=both

Contract notices and contract awards are continuously published here, so the website provides the potential for building a self-updating database.

\section{Internal World Bank Database}

Internal database of World Bank that contains a wider range of variables than the publicly available data. Our key variable, single bidding is from this database.

The combined complete datasets can be downloaded at http://www. govtransparency.eu/index.php/2018/02/13/data-publication-foreign-aid-of-world-bankeuropeaid-and-iadb/

\section{Appendix B Validity of single bidding as a corruption proxy}

As for what we refer to as 'macro validation' we checked the correlations with some well-established perception-based corruption indicators on country-level (similarly to (Fazekas \& Kocsis 2020)): World Governance Indicators' Control of Corruption, Transparency International's Corruption Perception Index, and Global Competitiveness Index's Favouritism in decisions of government officials (indicator $1.07^{13}$ ). All three perception indices indicate lower corruption with higher values, so we expect to see negative correlations (Kaufmann et al. 2009; Transparency International 2012; World Economic Forum 2010). This strategy has been originally used for national procurement data and for procurement notices published on Tender Electronic Daily (TED), the procurement page of the European Union; however, the corruption risks of procurement from development aid sources might not go hand in hand with the corruption patterns of national procurement. Furthermore, following from the regulations of the donor institutions (Fazekas \& Tóth 2014) contracts below countryspecific thresholds are not published on donor websites, thus we cannot even track the full amount of development aid spent through procurement (Fig. 2). It might be the case that suspicious transactions are managed below the threshold value and larger contracts are kept transparent. Consequently, we do not necessarily expect to see strong correlations with these indicators, but still, some level of correlation would strengthen the validity of our red flags.

The correlations with perception-based indicators for our most important red flag, single-bidding, are presented in Table 4. Single bidding is our most

\footnotetext{
${ }^{13}$ The question was, 'In your country, to what extent do government officials show favouritism to wellconnected firms and individuals when deciding upon policies and contracts? [ 1 = always show favouritism; 7 = never show favouritism]'.
} 
Table 4 Correlation of single bidding and perception-based corruption indicators

\begin{tabular}{llll}
\hline & TI-CPI (2009) & WGI-CoC (2009) & GCI-Fav (2009) \\
\hline Weighted with number of contracts & -0.20 & -0.15 & -0.20 \\
Weighted with sum of contract values & -0.18 & -0.11 & -0.15 \\
\hline
\end{tabular}

Note: Only countries with more than 100 contracts are considered

straight-forward red flag. In order to secure that resources are allocated to specific favoured individuals, other competitors should be somehow ruled out from competition. Unless fake competitors are commissioned, single bidding is necessary, but not sufficient sign of a tender.

We can see that all correlation coefficients of Table 4 are negative as expected but are not too high in absolute value. In Fig. 6, we depict the average 1998-2009 single bidder ratio with their 2009 WGI Control of Corruption scores to illustrate the relationship between the two. It is obvious that it is not a very strong and well-defined correlation, but it is evidently negative.

In addition to macro-level validity tests, we also employ micro-level validity regressions to gather further evidence on the likely association between single bidding and corruption (for a similar approach see Fazekas and Kocsis 2017). Specifically, we explore to what extent single bidding is associated with red flags related to procurement processes in World Bank-funded tenders (Table 5). Results are in line with our expectations, supporting the interpretation that single bidding is mainly driven by deliberate administrative choices for restricting competition in public procurement in line with our corruption definition.

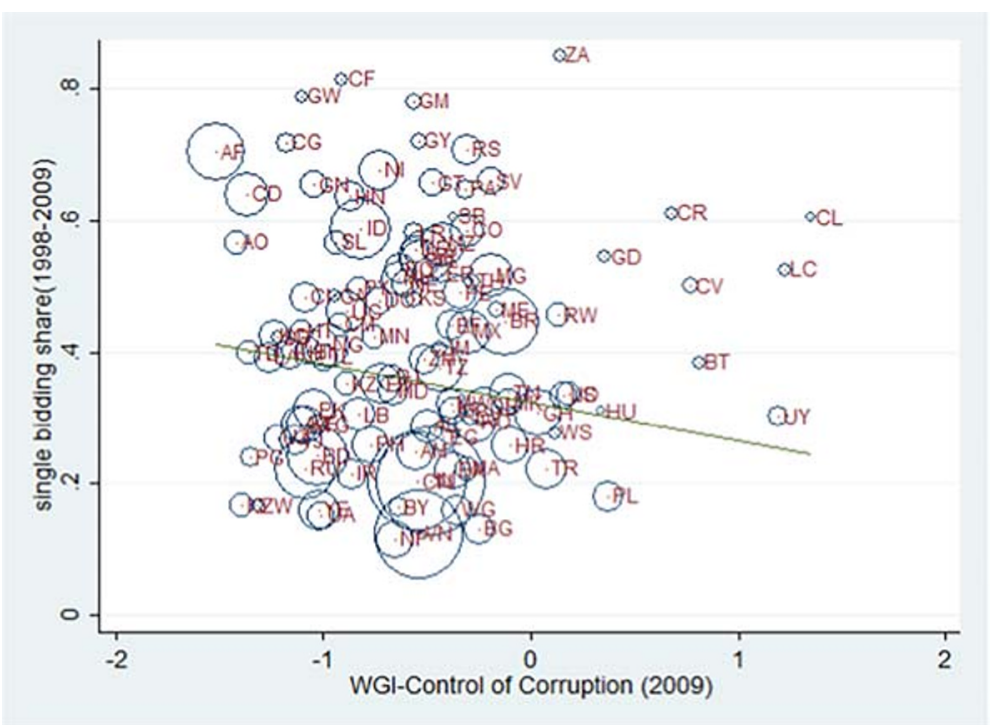

Fig. 6 Relationship between single-bidding ratio and WGI Control of Corruption indicator. Notes: The size of bubbles represents the number of contracts in that country. Number of contract per country used as weights. Only countries where there are more than 100 contracts are included 
Table 5 Micro validity testing. Coefficients from logit models predicting single bidding on tender level

\begin{tabular}{llll}
\hline Predictors/Dependent var. & & Single bid=1 \\
\hline Baseline: open procedure & & & \\
Procedure is restricted or single source & $2.69^{* *}$ & & $2.65^{* *}$ \\
Procedure is consultancy-oriented & $1.50^{* *}$ & & $1.49^{* *}$ \\
Baseline: 13 days $\leq$ signature period $\leq 93$ & & & \\
Signature period $<13$ days & & $0.42^{* *}$ & $0.19^{* *}$ \\
Signature period $>93$ days & & $0.32^{* *}$ & $0.07^{* *}$ \\
Missing signature period & & $0.76^{* *}$ & $0.33^{* *}$ \\
Log(contract value) & $\mathrm{x}$ & $\mathrm{x}$ & $\mathrm{x}$ \\
Sector & $\mathrm{x}$ & $\mathrm{x}$ & $\mathrm{x}$ \\
Country & $\mathrm{x}$ & $\mathrm{x}$ & $\mathrm{x}$ \\
Year & $\mathrm{x}$ & $\mathrm{x}$ & $\mathrm{x}$ \\
N contracts & 111,382 & 111,704 & 111,382 \\
Pseudo $R^{2}$ & 0.26 & 0.14 & 0.26 \\
\hline
\end{tabular}

**Significant at 0.01 level, *Significant at 0.05 level

\section{Appendix C Evidence for the absence of manipulation around the threshold}

The main question in assessing potential manipulation around the threshold is whether there was gaming in project approvals i.e. artificially postponing or bringing forward the approval in order to fall under the desired regulations. If actors follow such practices, our identification strategy would not be credible as we could not assume a quasi-random timing of project approvals around the intervention.

To test whether there was gaming, we first plotted the number of projects launched monthly in the years before and after the November 2003 intervention (Fig. 7) beginning with the latest and ending with the next intervention in WB regulations. We can see a strong seasonality in this graph with peaks in June each year that is the last month of a fiscal year at World Bank. According to this graph there was no extraordinary pattern around November 2003.

We also made some formal tests to make sure there is no irregular pattern in the timely distribution of project approvals around the intervention. On Fig. 8, we show the overlapping histograms of project approval dates monthly for the years preceding and following Nov 2003. The two distributions look very much alike and we did not find any significant differences between them with the two-sample Kolmogorov-Smirnov test and simple chi2 tests, either. We also tested the differences in distributions for broader time periods and for periods with November in the middle and we also did not find any significant differences in these versions. 


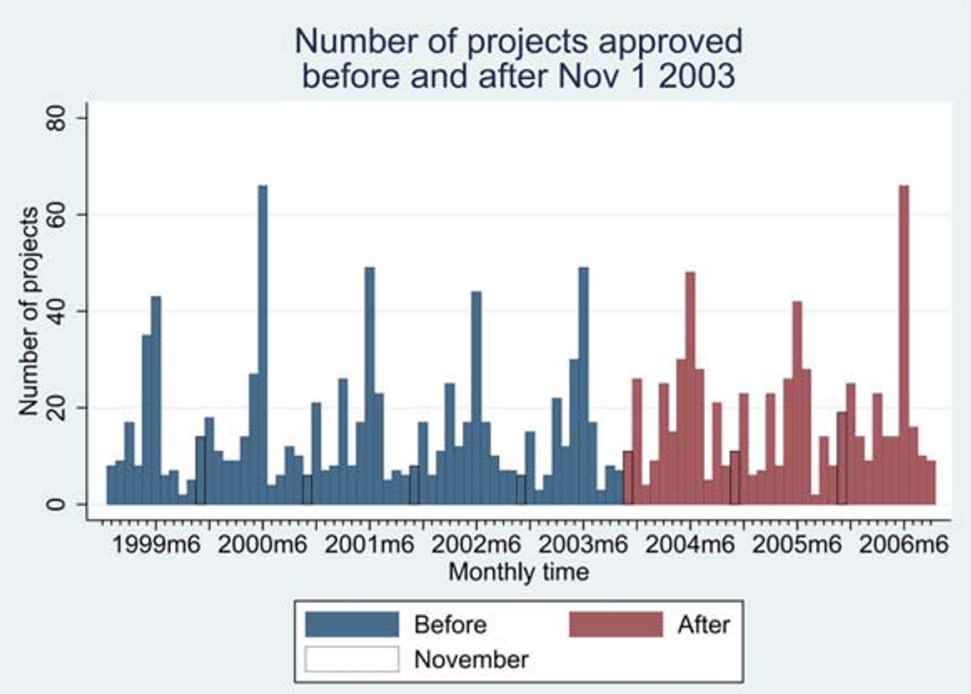

Fig. 7 Seasonal distribution of project approvals by months (Jan 1999-Sep 2006)

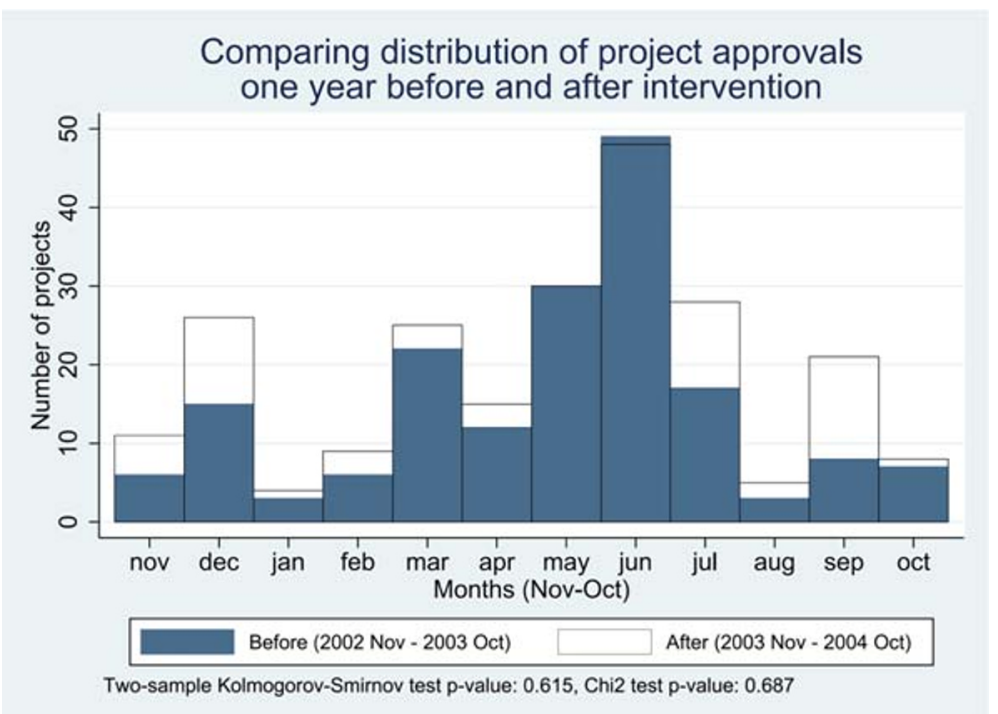

Fig. 8 Overlapping histograms of project approvals (monthly) for the years preceding and the following year of Nov 1, 2003 


\section{Appendix D Descriptive statistics}

Table 6 Simple statistics about the variables used in the estimations, contracts above 25,000 USD, goods and works, 2000-2008

\begin{tabular}{llllll}
\hline Variable & Obs. & Mean & Std. dev. & Min & Max \\
\hline $\begin{array}{lllll}\text { Single bidding } \\
\begin{array}{l}\text { ANB-level single bidding } \\
\quad \text { before intervention }\end{array}\end{array}$ & 28,818 & 0.22 & 0.42 & 0 & 1 \\
$\begin{array}{l}\text { Country-level single bidding } \\
\quad \text { before intervention }\end{array}$ & 31,139 & 0.23 & 0.33 & 0 & 1 \\
Contract value & & & & & \\
Log of contract value & 31,701 & $4,711,109$ & $23,100,000$ & 38,726 & $2,130,000,000$ \\
Party system institutionalization & 31,701 & 13.73 & 1.56 & 10.56 & 21.48 \\
State capacity & 30,709 & 0.01 & 0.81 & -2.36 & 1.25 \\
Sectors & 30,132 & -0.29 & 0.63 & -2.58 & 1.73 \\
$\quad$ Agriculture & & & & & \\
Education & 31,701 & 0.09 & 0.28 & 0 & 1 \\
Finance & 31,701 & 0.13 & 0.34 & 0 & 1 \\
Energy \& mining & 31,701 & 0.11 & 0.31 & 0 & 1 \\
Finance & 31,701 & 0.01 & 0.12 & 0 & 1 \\
Industry and trade & 31,701 & 0.17 & 0.38 & 0 & 1 \\
Info \& communication & 31,701 & 0.03 & 0.16 & 0 & 1 \\
$\quad$ Public admin, law & 31,701 & 0.01 & 0.09 & 0 & 1 \\
$\quad$ Transportation & 31,701 & 0.16 & 0.37 & 0 & 1 \\
Water, sanitation, flood protection & 31,701 & 0.17 & 0.37 & 0 & 1 \\
\hline & 31,701 & 0.13 & 0.33 & 0 & 1 \\
\hline
\end{tabular}

Table 7 List of countries and the number of contracts per country in the sample, contracts above 25,000 USD, goods and works, 2000-2008

\begin{tabular}{llll}
\hline Country name & Freq. & Percent & Cum. percent \\
\hline Afghanistan & 495 & 1.57 & 1.57 \\
Albania & 350 & 1.11 & 2.69 \\
Algeria & 23 & 0.07 & 2.76 \\
Angola & 52 & 0.17 & 2.92 \\
Argentina & 228 & 0.72 & 3.65 \\
Armenia & 478 & 1.52 & 5.17 \\
Azerbaijan & 224 & 0.71 & 5.88 \\
Bangladesh & 1118 & 3.55 & 9.43 \\
Barbados & 9 & 0.03 & 9.46 \\
Belarus & 55 & 0.17 & 9.64 \\
Belize & 24 & 0.08 & 9.71 \\
Benin & 282 & 0.9 & 10.61
\end{tabular}


Table 7 (continued)

\begin{tabular}{|c|c|c|c|}
\hline Country name & Freq. & Percent & Cum. percent \\
\hline Bhutan & 115 & 0.37 & 10.98 \\
\hline Bolivia & 126 & 0.4 & 11.38 \\
\hline Bosnia and Herzegovina & 618 & 1.96 & 13.34 \\
\hline Brazil & 466 & 1.48 & 14.82 \\
\hline Bulgaria & 515 & 1.64 & 16.46 \\
\hline Burkina Faso & 165 & 0.52 & 16.98 \\
\hline Burundi & 397 & 1.26 & 18.24 \\
\hline Cambodia & 219 & 0.7 & 18.94 \\
\hline Cameroon & 56 & 0.18 & 19.12 \\
\hline Cape Verde & 77 & 0.24 & 19.36 \\
\hline Central African Republic & 7 & 0.02 & 19.39 \\
\hline Chad & 162 & 0.51 & 19.9 \\
\hline Chile & 10 & 0.03 & 19.93 \\
\hline China & 2699 & 8.58 & 28.51 \\
\hline Colombia & 101 & 0.32 & 28.83 \\
\hline Comoros & 26 & 0.08 & 28.91 \\
\hline Congo & 103 & 0.33 & 29.24 \\
\hline Costa Rica & 11 & 0.03 & 29.28 \\
\hline Cote d'Ivoire & 2 & 0.01 & 29.28 \\
\hline Croatia & 345 & 1.1 & 30.38 \\
\hline Democratic Republic of the Congo & 301 & 0.96 & 31.34 \\
\hline Djibouti & 141 & 0.45 & 31.78 \\
\hline Dominica & 13 & 0.04 & 31.83 \\
\hline Dominican Republic & 78 & 0.25 & 32.07 \\
\hline Ecuador & 44 & 0.14 & 32.21 \\
\hline Egypt & 127 & 0.4 & 32.62 \\
\hline El Salvador & 69 & 0.22 & 32.84 \\
\hline Eritrea & 184 & 0.58 & 33.42 \\
\hline Estonia & 13 & 0.04 & 33.46 \\
\hline Ethiopia & 327 & 1.04 & 34.5 \\
\hline Gabon & 5 & 0.02 & 34.52 \\
\hline Gambia & 74 & 0.24 & 34.75 \\
\hline Georgia & 493 & 1.57 & 36.32 \\
\hline Ghana & 590 & 1.88 & 38.2 \\
\hline Grenada & 83 & 0.26 & 38.46 \\
\hline Guatemala & 102 & 0.32 & 38.78 \\
\hline Guinea & 277 & 0.88 & 39.66 \\
\hline Guinea-Bissau & 31 & 0.1 & 39.76 \\
\hline Guyana & 41 & 0.13 & 39.89 \\
\hline Haiti & 25 & 0.08 & 39.97 \\
\hline Honduras & 161 & 0.51 & 40.48 \\
\hline Hungary & 9 & 0.03 & 40.51 \\
\hline
\end{tabular}


Table 7 (continued)

\begin{tabular}{|c|c|c|c|}
\hline Country name & Freq. & Percent & Cum. percent \\
\hline India & 2651 & 8.43 & 48.94 \\
\hline Indonesia & 385 & 1.22 & 50.16 \\
\hline Iran & 452 & 1.44 & 51.6 \\
\hline Iraq & 248 & 0.79 & 52.39 \\
\hline Jamaica & 32 & 0.1 & 52.49 \\
\hline Jordan & 136 & 0.43 & 52.92 \\
\hline Kazakhstan & 89 & 0.28 & 53.2 \\
\hline Kenya & 140 & 0.44 & 53.65 \\
\hline Kosovo & 60 & 0.19 & 53.84 \\
\hline Kyrgyzstan & 179 & 0.57 & 54.41 \\
\hline Lao People's Democratic Republic & 166 & 0.53 & 54.94 \\
\hline Latvia & 111 & 0.35 & 55.29 \\
\hline Lebanon & 416 & 1.32 & 56.61 \\
\hline Lesotho & 186 & 0.59 & 57.2 \\
\hline Liberia & 13 & 0.04 & 57.24 \\
\hline Lithuania & 68 & 0.22 & 57.46 \\
\hline Macedonia & 97 & 0.31 & 57.77 \\
\hline Madagascar & 401 & 1.27 & 59.04 \\
\hline Malawi & 127 & 0.4 & 59.45 \\
\hline Malaysia & 53 & 0.17 & 59.61 \\
\hline Maldives & 6 & 0.02 & 59.63 \\
\hline Mali & 191 & 0.61 & 60.24 \\
\hline Mauritania & 258 & 0.82 & 61.06 \\
\hline Mauritius & 2 & 0.01 & 61.07 \\
\hline Mexico & 457 & 1.45 & 62.52 \\
\hline Moldova & 173 & 0.55 & 63.07 \\
\hline Mongolia & 136 & 0.43 & 63.5 \\
\hline Montenegro & 26 & 0.08 & 63.58 \\
\hline Morocco & 94 & 0.3 & 63.88 \\
\hline Mozambique & 349 & 1.11 & 64.99 \\
\hline Nepal & 409 & 1.3 & 66.29 \\
\hline Nicaragua & 331 & 1.05 & 67.34 \\
\hline Niger & 112 & 0.36 & 67.7 \\
\hline Nigeria & 619 & 1.97 & 69.67 \\
\hline Pakistan & 371 & 1.18 & 70.85 \\
\hline Panama & 44 & 0.14 & 70.99 \\
\hline Papua New Guinea & 218 & 0.69 & 71.68 \\
\hline Paraguay & 24 & 0.08 & 71.76 \\
\hline Peru & 131 & 0.42 & 72.17 \\
\hline Philippines & 648 & 2.06 & 74.23 \\
\hline Poland & 65 & 0.21 & 74.44 \\
\hline Romania & 471 & 1.5 & 75.94 \\
\hline
\end{tabular}


Table 7 (continued)

\begin{tabular}{|c|c|c|c|}
\hline Country name & Freq. & Percent & Cum. percent \\
\hline Russian Federation & 637 & 2.02 & 77.96 \\
\hline Rwanda & 147 & 0.47 & 78.43 \\
\hline Saint Kitts and Nevis & 21 & 0.07 & 78.49 \\
\hline Saint Lucia & 63 & 0.2 & 78.69 \\
\hline Saint Vincent and the Grenadines & 36 & 0.11 & 78.81 \\
\hline Samoa & 59 & 0.19 & 79 \\
\hline Sao Tome and Principe & 6 & 0.02 & 79.02 \\
\hline Senegal & 365 & 1.16 & 80.18 \\
\hline Serbia & 158 & 0.5 & 80.68 \\
\hline Seychelles & 1 & 0 & 80.68 \\
\hline Sierra Leone & 181 & 0.58 & 81.26 \\
\hline Slovakia & 3 & 0.01 & 81.27 \\
\hline Slovenia & 9 & 0.03 & 81.29 \\
\hline Solomon Islands & 3 & 0.01 & 81.3 \\
\hline South Africa & 15 & 0.05 & 81.35 \\
\hline South Sudan & 54 & 0.17 & 81.52 \\
\hline Sri Lanka & 98 & 0.31 & 81.84 \\
\hline Sudan & 14 & 0.04 & 81.88 \\
\hline Syrian Arab Republic & 2 & 0.01 & 81.89 \\
\hline Tajikistan & 439 & 1.4 & 83.28 \\
\hline Thailand & 23 & 0.07 & 83.35 \\
\hline Timor-Leste & 249 & 0.79 & 84.15 \\
\hline Tonga & 16 & 0.05 & 84.2 \\
\hline Trinidad and Tobago & 31 & 0.1 & 84.3 \\
\hline Tunisia & 278 & 0.88 & 85.18 \\
\hline Turkey & 302 & 0.96 & 86.14 \\
\hline Uganda & 361 & 1.15 & 87.29 \\
\hline Ukraine & 128 & 0.41 & 87.69 \\
\hline United Republic of Tanzania & 293 & 0.93 & 88.62 \\
\hline Uruguay & 60 & 0.19 & 88.82 \\
\hline Uzbekistan & 167 & 0.53 & 89.35 \\
\hline Venezuela & 7 & 0.02 & 89.37 \\
\hline Vietnam & 2233 & 7.1 & 96.47 \\
\hline West Bank and Gaza & 369 & 1.17 & 97.64 \\
\hline Yemen & 459 & 1.46 & 99.1 \\
\hline Zambia & 284 & 0.9 & 100 \\
\hline Total & 31,462 & 100 & \\
\hline
\end{tabular}




\section{Appendix E Goodness of fit for propensity score matching}

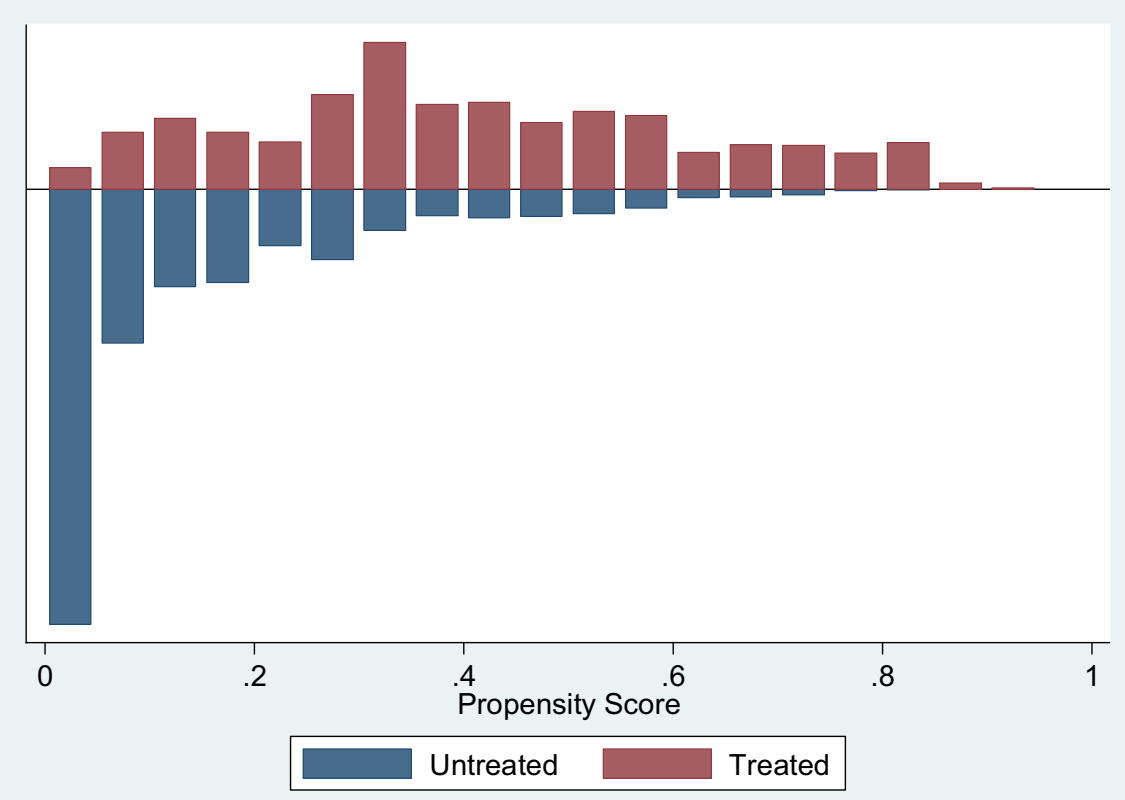

Fig. 9 Comparison of propensity scores in the control and treatment groups

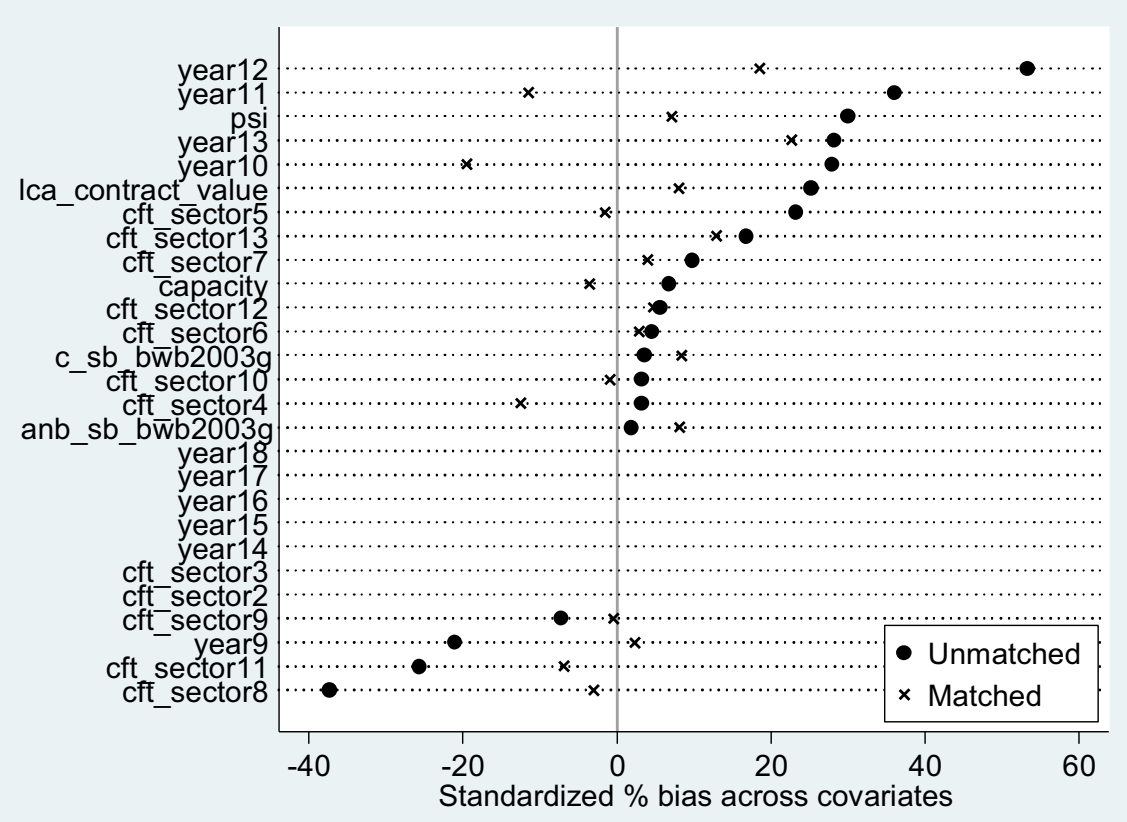

Fig. 10 Variable level balance in the matched and unmatched comparisons 
Table 8 Summary of balance before and after matching

\begin{tabular}{lllllllll}
\hline Sample & Ps $R^{2}$ & LR chi & $p>\mathrm{chi}^{2}$ & Mean bias & Median bias & $B$ & $R$ & $\%$ Var \\
\hline Unmatched & 0.256 & 1721.74 & 0 & 18.5 & 18.9 & $142.6^{*}$ & 0.57 & 60 \\
Matched & 0.025 & 95.22 & 0 & 8 & 7 & $37.2^{*}$ & 1.96 & 60 \\
\hline
\end{tabular}

* if $\mathrm{B}>25 \%, \mathrm{R}$ outside $[0.5 ; 2]$

\section{Appendix F Robustness tests-competitive procedures only}

Table 9 Simple and matched comparisons of treatment and control groups, single bidder \%, contracts above 25,000 USD, goods and works, 2003-2008, competitive procedures only

\begin{tabular}{|c|c|c|c|c|}
\hline & Raw comparison & Matching (1) & Matching (2) & Matching (3) \\
\hline \multicolumn{5}{|l|}{ Single bidder dummy } \\
\hline Control & $17.98 \%$ & $16.63 \%$ & $18.46 \%$ & $19.61 \%$ \\
\hline Treatment & $11.13 \%$ & $11.11 \%$ & $10.04 \%$ & $10.06 \%$ \\
\hline diff(Treatment - Control) & $-6.85 \% * * *$ & $-5.52 \% * * *$ & $-8.42 \% * * *$ & $-9.55 \% * * *$ \\
\hline $95 \%$ c. interval: lower bound & $-8.06 \%$ & $-6.92 \%$ & $-11.16 \%$ & $-12.40 \%$ \\
\hline $95 \%$ c. interval: upper bound & $-5.64 \%$ & $-4.13 \%$ & $-5.68 \%$ & $-6.70 \%$ \\
\hline$N$ control & 11,488 & 4675 & 1238 & 1208 \\
\hline$N$ treatment & 4996 & 4675 & 1238 & 1208 \\
\hline \multicolumn{5}{|l|}{ Matching variables } \\
\hline $\log ($ contract value $)$ & & $\mathrm{Y}$ & $\mathrm{Y}$ & $\mathrm{Y}$ \\
\hline Main sector & & $\mathrm{Y}$ & $\mathrm{Y}$ & $\mathrm{Y}$ \\
\hline Country & & $\mathrm{Y}$ & & \\
\hline Continent & & $\mathrm{Y}$ & & \\
\hline Year & & $\mathrm{Y}$ & $\mathrm{Y}$ & $\mathrm{Y}$ \\
\hline Country prior single bidder $\%$ & & & $\mathrm{Y}$ & $\mathrm{Y}$ \\
\hline Buyer prior single bidder $\%$ & & & $\mathrm{Y}$ & $\mathrm{Y}$ \\
\hline Country state capacity & & & & $\mathrm{Y}$ \\
\hline Country PSI & & & & $\mathrm{Y}$ \\
\hline
\end{tabular}

Significance levels: $* * *<0.1 \%, * *<1 \%, *<5 \%$ 
Table 10 Binary logistic regressions explaining single bidder contracts, contracts above 25,000 USD, goods and works, 2004-2007+ (log-odds coefficients and p-values are reported), competitive procedures only

Model

(1)

(2)

(3)

(4)

(5)

Single bidder dummy

2003 GWS intervention

$\begin{array}{lllll}-0.332^{* * * *} & -0.348^{* * * *} & -0.381^{* * *} & -0.329^{* * *} & -0.221^{* *} \\ (0.000) & (0.000) & (0.000) & (0.000) & (0.009) \\ & -0.27 & & -0.493 & \\ & (0.321) & & (0.298) & \\ & & -0.416^{* *} & & -0.493 \\ & & (0.003) & & (0.059) \\ & & & -0.128 & \\ & & & (0.128) & \end{array}$

institutionalization

$0.428^{* * *}$

2003 GWS intervention=1 \# State capacity

Control variables

Log contract value

Main sector

Country

Year

Constant

Observations

$\begin{array}{lllll}\mathrm{Y} & \mathrm{Y} & \mathrm{Y} & \mathrm{Y} & \mathrm{Y} \\ \mathrm{Y} & \mathrm{Y} & \mathrm{Y} & \mathrm{Y} & \mathrm{Y} \\ \mathrm{Y} & \mathrm{Y} & \mathrm{Y} & \mathrm{Y} & \mathrm{Y} \\ \mathrm{Y} & \mathrm{Y} & \mathrm{Y} & \mathrm{Y} & \mathrm{Y} \\ \mathrm{Y} & \mathrm{Y} & \mathrm{Y} & \mathrm{Y} & \mathrm{Y} \\ 13,759 & 22,345 & 21,988 & 13,535 & 13,288 \\ 0.208 & 0.178 & 0.176 & 0.208 & 0.207\end{array}$

Significance levels: $* * *<0.1 \% ; * *<1 \% ; *<5 \%$ 


\section{Appendix G Robustness tests - Matching estimation and interactions}

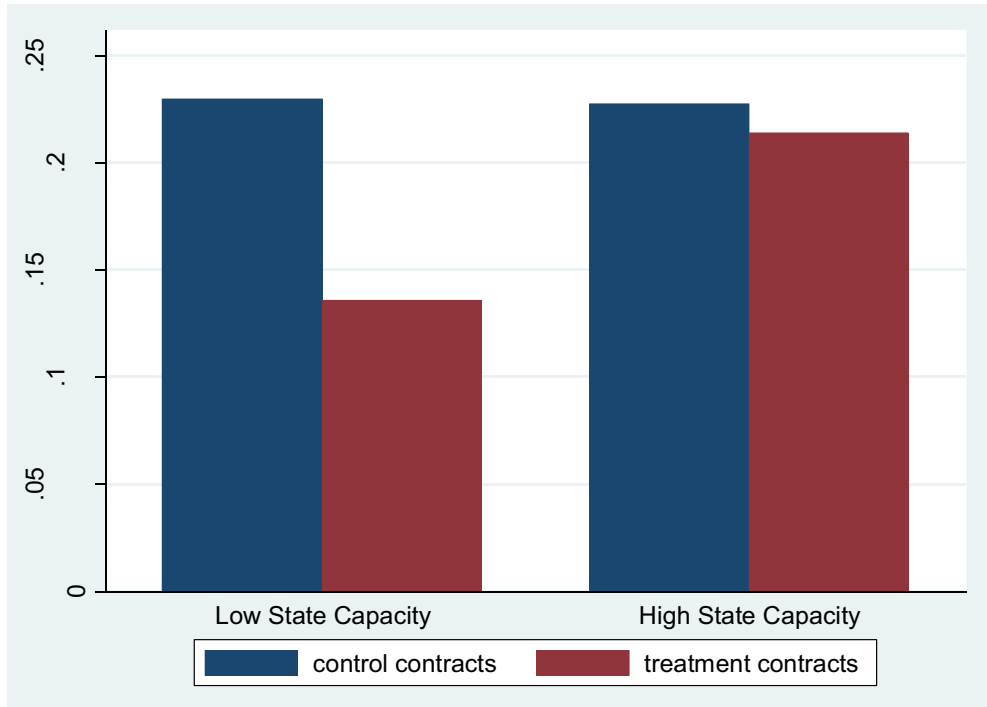

Fig. 11 Comparison of control and treatment group single-bidder ratios, low vs high state capacity subsamples, propensity score matching (Table 2, matching(3)), World Bank public procurement, goods, works and services, 2003-2014

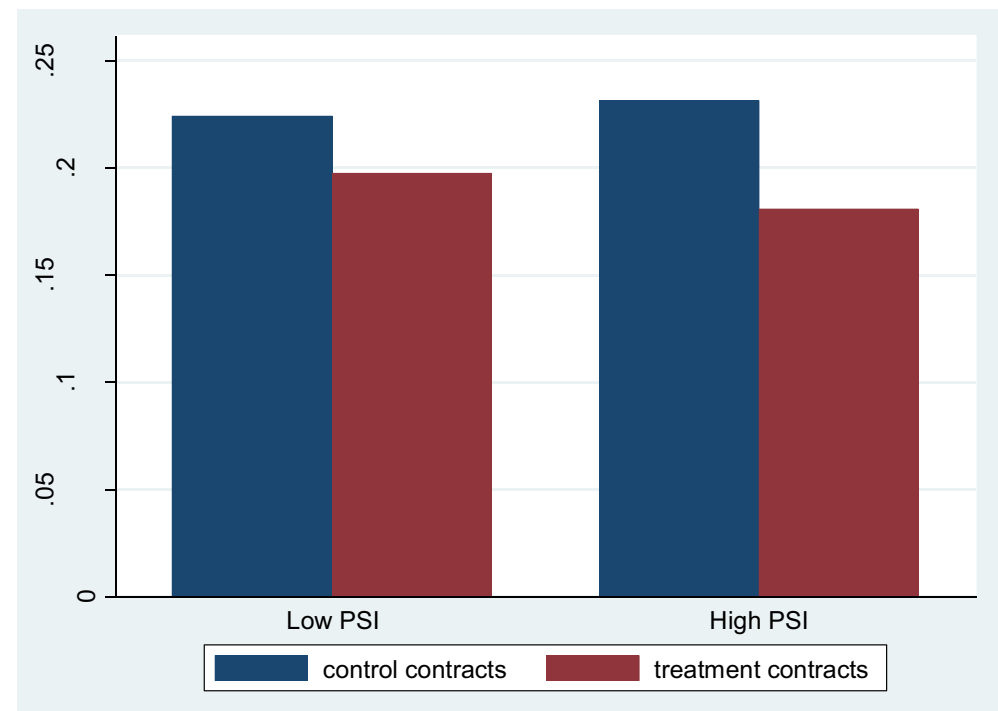

Fig. 12 Comparison of control and treatment group single-bidder ratios, low vs high PSI subsamples, propensity score matching (Table 2, matching(3)), World Bank public procurement, goods, works and services, 2003-2014 
Open Access This article is licensed under a Creative Commons Attribution 4.0 International License, which permits use, sharing, adaptation, distribution and reproduction in any medium or format, as long as you give appropriate credit to the original author(s) and the source, provide a link to the Creative Commons licence, and indicate if changes were made. The images or other third party material in this article are included in the article's Creative Commons licence, unless indicated otherwise in a credit line to the material. If material is not included in the article's Creative Commons licence and your intended use is not permitted by statutory regulation or exceeds the permitted use, you will need to obtain permission directly from the copyright holder. To view a copy of this licence, visit http://creativecommons.org/licenses/by/4.0/.

\section{References}

Alesina A, Weder B. Do corrupt governments receive less foreign aid? Am Econ Rev. 2002;92(4):1126-37. Andrews M, Pritchett L, Woolcock M. Escaping capability traps through Problem-Driven Iterative Adaptation (PDIA). World Dev. 2012;51:234 44.

Asongu SA, Nwachukwu JC. Foreign aid and governance in Africa. Int Rev Appl Econ. 2016;30(1):69-88.

Auriol E. Corruption in procurement and public purchase. Int J Ind Organ. 2006;24(5):867-85.

Avis, E., Ferraz, C. \& Finan, F., 2016. Do government audits reduce corruption? Estimating the impacts of exposing corrupt politicians,

Bizzarro F, Gerring J, Knutsen CH, Hicken A, Bernhard M, Skaaning SE, et al. Party strength and economic growth. World Polit. 2018;70(2):275-320.

Brautigam D. Governance, economy, and foreign aid. Stud Comp Int Dev. 1992;27(3):3-25.

Brautigam D, Fjeldstad OH, Moore M, editors. Taxation and state-building in developing countries: Capacity and consent. Cambridge University Press. 2008.

Bräutigam DA, Knack S. Foreign aid, institutions, and governance in sub-Saharan Africa. Econ Dev Cult Chang. 2004;52(2):255-85.

Broms R, Dahlström C, Fazekas M. Political competition and public procurement quality. Gothenburg. 2017.

Brunetti A, Weder B. A free press is bad news for corruption. J Public Econ. 2003;87(7-8):1801-24.

Bueno de Mesquita B, et al. The logic of political survival. Cambridge and London: The MIT Press; 2003.

Busse M, Gröning S. Does foreign aid improve governance? Econ Lett. 2009;104(2):76-8.

Caputo E, De Kemp A, Lawson A. Assessing the impacts of budget support case studies in Mali, Tunisia and Zambia. Evaluation Insights. 2011;2:1-8 Available at: www.oecd.org/dac/evaluation.

Carothers T, De Gramont D. Development aid confronts politics: The almost revolution. Brookings Institution Press; 2013 Apr 1.

Charron N. Exploring the impact of foreign aid on corruption: has the "anti-corruption movement" been effective? Dev Econ. 2011;49(1):66-88.

Charron N, Dahlström C, Fazekas M, Lapuente V. Careers, connections, and corruption risks: investigating the impact of bureaucratic meritocracy on public procurement processes. J Polit. 2017;79(1):89-104.

Collier, P., Kirchberger, M. \& Söderbrom, M., 2015. The cost of road infrastructure in low and middle income countries.

Cordella T, Dell'Ariccia G. Budget support versus project aid: a theoretical appraisal. Econ J. 2007;117(523): 1260-79.

Cordis AS, Milyo J. Measuring public corruption in the United States: evidence from administrative records of federal prosecutions. Public Integrity. 2016;18:127-48.

Coviello D, Mariniello M. Publicity requirements in public procurement: evidence from a regression discontinuity design. J Public Econ. 2014;109:76-100.

Dalgaard C-J, Olsson O. Windfall gains, political economy and economic development. J Afr Econ. 2008;17(Supplement 1):72-109.

Dávid-Barrett E, Fazekas M. Grand corruption and government change: an analysis of partisan favoritism in public procurement. Eur J Crim Policy Res. 2019:1-20.

De Renzio P. Aid, budgets and accountability: a survey article. Dev Policy Rev. 2006;24(6):627-45.

Deaton A. The great escape: health, wealth, and the origins of inequality: Princeton University Press; 2013.

Di Tella R, Schargrodsky E. The role of wages and auditing during a crackdown on corruption in the city of Buenos Aires. J Law Econ. 2003;46(1):269-92.

Dijkstra G, de Kemp A. Challenges in evaluating budget support and how to solve them. Evaluation. 2015;21(1):83-98 Available at: http://evi.sagepub.com/content/21/1/83.abstract.

Ear S. Does aid dependence worsen governance? Int Public Manag J. 2007;10(3):259-86. 
Easterly W, Pfutze T. Where does the money go? Best and worst practices in foreign aid. J Econ Perspect. 2008;22/2:29-52.

Ellmers B. Helping or hindering? Procurement, tied aid and the use of country systems in Bangladesh. 2011

Escresa L, Picci L. A new cross-national measure of corruption. World Bank Econ Rev. 2015:1hv031.

Escresa L, Picci L. Trends in corruptions around the world. Eur J Crim Policy Res. 2016;22(3):543-64.

Fazekas, M. \& Blum, J.R., 2020. Improving public procurement outcomes: review of tools and the state of evidence base, Washington, DC.

Fazekas M, Kocsis G. Uncovering High-Level Corruption: Cross-NationalCorruption Proxies Using Government Contracting Data. British Journal of PoliticalScience. 2017. https://doi.org/10.1017 /S0007123417000461.

Fazekas M, Kocsis G. Uncovering High-Level Corruption: Cross-National Objective Corruption Risk Indicators Using Public Procurement Data. British Journal of Political Science. 2020;50(1):155-164.

Fazekas M, Tóth IJ. Indicators of high-level corruption using World Bank public procurement data. 2014.

Gomez ET, Jomo KS. Malaysia's political economy: politics, Patronage and Profits. Cambridge: Cambridge University Press; 1999.

Grindle MS. Good Enough Governance Revisited. Development Policy Review. 2007;25(5):533-574

Grimes M. The contingencies of societal accountability: examining the link between civil society and good government. Stud Comp Int Dev. 2013;48(4):380-402.

Haber S. Authoritarian government. In: Weingast BR, Wittman D, editors. The Oxford handbook of political economy. Oxford and New York: Oxford University Press; 2006. p. 693-707.

Hanson J, Sigman R. Leviathan's latent dimensions: measuring state capacity for comparative political research: Manuscript, Maxwell School of Citizenship and Public Affairs, Syracuse University; 2013. p. $1-41$.

Heywood PM, Rose J. "Close but no cigar": the measurement of corruption. Journal of Public Policy. 2014;34(03):507-29.

Hicken A, Martinez Kuhonta E. Shadows from the past: party system institutionalization in Asia. Comparative Political Stud. 2011;44(5):572-97.

Kang DC. Bad loans to good friends: money politics and the developmental state in South Korea. Int Organ. 2002;56(1):177-207.

Kangoye T. Does aid unpredictability weaken governance? Evidence from developing countries. Dev Econ. 2013;51(2):121-44.

Kaufmann D, Kraay A, Mastruzzi M. Governance Matters VIII. Washington, DC: World Bank; 2009.

Kelsall T. Business, politics, and the state in Africa: challenging the orthodoxies on growth and transformation. London and New York: Zed Books; 2013.

Kenny C, Crisman B. Results through transparency: does publicity Lead to better procurement? DC: Washington; 2016.

Kenny C, Musatova M. Red flags of corruption. In: World Bank projects: an analysis of infrastructure contracts, Washington, DC; 2010.

Khan MH. Patron-client networks and the economic effects of corruption in Asia. Eur J Dev Res. 1998;10(1): 15-39.

Khan, M.H., 2010. Political settlements and the governance of growth-enhancing institutions,

Klasnja M. Corruption and the incumbency disadvantage: theory and evidence. J Polit. 2016;77(4):928-42.

Klitgaard R. Controlling corruption. Berkeley, CA: University of California Press; 1991.

Knack S, Rahman A. Donor fragmentation and bureaucratic quality in aid recipients. J Dev Econ. 2007;83(1): 176-97.

Knack, S., Biletska, N. \& Kacker, K., 2017. Deterring kickbacks and encouraging entry in public procurement markets evidence from firm surveys in 88 developing countries, Available at: http://documents. worldbank.org/curated/en/817871496169519447/pdf/WPS8078.pdf.

Ko K, Samajdar A. Evaluation of international corruption indexes: should we believe them or not? Soc Sci J. 2010;47(3):508-40.

Kolstad, I. \& Fritz, V., 2008. Corruption and aid modalities, Available at: http://www.u4. no/publications/corruption-and-aid-modalities/.

Kuhonta EM. The institutional imperative : the politics of equitable development in Southeast Asia: Stanford University Press; 2011.

Lancaster TD, Montinola GR. Comparative political corruption: issues of operationalization and measurement. Stud Comp Int Dev. 2001;36(3):3-28.

Landry PF. The political management of mayors in post-Deng China. Copenhagen Journal of Asian Studies. 2003;17:31-58. 
Lewis-Faupel S, Neggers Y, Olken BA, Pande R. Can Electronic Procurement Improve Infrastructure Provision? Evidence from Public Works in India and Indonesia. American Economic Journal: Economic Policy. 2016;8(3):258-283

Mainwaring S. Party systems in the third wave. J Democr. 1998;9(3):67-81.

Menard A-R, Weill L. Understanding the link between aid and corruption: a causality analysis. Econ Syst. 2016;40(2):260-72.

Migdal JS. Strong societies and weak states: state-society relations and state capabilities in the Third World. Princeton University Press. 1988.

Mohamed MR, Kaliappan SR, Ismail NW, Azman-Saini WNW. Effect of foreign aid on corruption: evidence from sub-Saharan African countries. Int J Soc Econ. 2015;42(1):47-63.

Mungiu A. Corruption: diagnosis and treatment. J Democr. 2006;17(3):86-99.

Mungiu-Pippidi A, Dadašov R. When do anticorruption laws matter? The evidence on public integrity enabling contexts. Crime, Law and Social Change, available. 2017;68:387-402.

North DC, Wallis JJ, Weingast BR. Violence and social orders: a conceptual framework for interpreting recorded human history: Cambridge University Press; 2009.

OECD. Harmonising donor practices for effective aid delivery. Paris: OECD; 2003.

Öhler H, Nunnenkamp P, Dreher A. Does conditionality work? A test for an innovative US aid scheme. Eur Econ Rev. 2012;56(1):138-53.

Okada K, Samreth S. The effect of foreign aid on corruption: a quantile regression approach. Econ Lett. 2012;115(2):240-3.

Olken BA. Monitoring corruption: evidence from a field experiment in Indonesia. J Polit Econ. 2007;115(2): $200-49$.

Perakis, R., \& Savedoff, W. (2015). Does results-based aid change anything? Pecuniary interests, attention, accountability and discretion in four case studies. CGD policy paper, 52.

Radelet S. Pushing or pulling reforms: Center for Global Development, Working Paper Nr 53, (53); 2005.

Rasmussen M, Knutsen CH. Party institutionalization and welfare state development. In: V-Dem Working Paper 55; 2017.

Razafindrakoto M, Roubaud F. Are international databases on corruption reliable? A comparison of expert opinion surveys and household surveys in sub-Saharan Africa. World Dev. 2010;38(8):1057-69.

Rocha Menocal A. Getting real about politics. From thinking politically to working differently. London; 2014.

Rock MT, Bonnett H. The comparative politics of corruption: accounting for the east Asian paradox in empirical studies of corruption, growth and investment. World Dev. 2004;32(6):999-1017.

Rose-Ackerman S, Palifka BJ. Corruption and government: causes, consequences and reform. 2nd ed: Cambridge University press; 2016.

Rothstein BO, Teorell JA. What is quality of government? A theory of impartial government institutions. Governance. 2008;21(2):165-90.

Rueschemeyer D. Building states - inherently a long-term process? An argument from theory. In: Lange M, Rueschemeyer D, editors. States and development: historical antecedents of stagnation and advance. New York: Palgrave Macmillan; 2005. p. 143-64.

Schleiter P, Voznaya A. Party system institutionalization, accountability and governmental corruption. British Journal of Political Science. 2016:1-28.

Skocpol T. Bringing the state back in: strategies of analysis in current research. In: Evans PB, Rueschemeyer D, Skocpol T, editors. Bringing the state back in. New York: Cambridge University Press; 1985. p. 3-37.

Singer M, Konstantinidis G, Roubik E, Beffermann E. Does e-procurement save the state money?. Journal of Public Procurement. 2009;9(1):58-78

Søreide T. Corruption in public procurement. Causes, consequences and cures. Chr: Michelsen Intitute; 2002.

Svensson J. Foreign aid and rent-seeking. J Int Econ. 2000;51(2):437-61.

Tavares J. Does foreign aid corrupt? Econ Lett. 2003;79(1):99-106.

Tavits M. Clarity of responsibility and corruption. Am J Polit Sci. 2007;51(1):218-29.

Transparency International. Corruption Perceptions Index 2012. Berlin: Transparency International; 2012.

Ware, G.T. et al., 2007. Corruption in public procurement: a perennial challenge. In J. E. Campos \& S. Pradhan, eds. The many faces of corruption. Tracking vulnerabilities at the sector level. Washington, DC: World Bank.

Wedeman A. Looters, rent-scrapers, and dividend-collectors: corruption and growth in Zaire, South Korea, and the Philippines. J Dev Areas. 1997;31(4):457-78.

White HN, Dijkstra AG. Programme aid and development - beyond conditionality. London: Routledge; 2003.

Winters MS, Weitz-Shapiro R. Lacking information or condoning corruption: when do voters support corrupt politicians? Comparative Politics. 2013;45(4):418-36. 
World Economic Forum. The Global Competitiveness Report 2010-2011. Geneva: World Economic Forum; 2010.

World Bank. Benchmarking public procurement 2015: Washington, DC, US; 2015a.

World Bank. 2015 development policy financing retrospective. Results and sustainability. Washington, DC, US; $2015 b$.

World Bank Integrity Presidency. Fraud and corruption. Awareness handbook. Washington DC: World Bank; 2009.

Wright J. To invest or insure? Comparative Political Studies. 2008;41(7):971-1000.

Zamboni Y, Litschig S. Audit risk and rent extraction: evidence from a randomized evaluation in Brazil. Journal of Development Economics. 2017, 134:133-149.

Publisher's Note Springer Nature remains neutral with regard to jurisdictional claims in published maps and institutional affiliations.

Elizabeth Dávid-Barrett is Professor of Governance and Integrity at the University of Sussex, and Director of the Centre for the Study of Corruption. Her work focuses on corruption risks at the interface of business and politics, and how they are influenced by laws and social norms.

Mihály Fazekas is an assistant professor at the Central European University, School of Public Policy, and he is the director of the Government Transparency Institute. His main interests lie in applying Big Data methods to improve anti-corruption policies.

Olli Hellmann is Senior Lecturer in Political Science at the University of Waikato, Aotearoa New Zealand. His current research agenda focuses on questions of legitimacy and legitimation in non-democratic regimes.

Lili Márk is a PhD candidate at the Central European University.

Ciara McCorley is a Research Fellow at the University of Sussex. 